ISSN No. 2454 - 1427

\title{
LOCAL INSTITUTIONAL STRUCTURE AND CLIENTELISTIC ACCESS TO EMPLOYMENT: THE CASE OF MGNREGS IN THREE STATES OF INDIA
}

\author{
Anindya Bhattacharya \\ Department of Economics \\ Related Studies, University of York \\ Anirban Kar \\ Email: anirban@econdse.org \\ Department of Economics \\ Delhi School of Economics \\ Alita Nandi \\ Email: anandi@essex.ac.uk \\ ISER, University of Essex
}

\section{Working Paper No. 269}

http://www.cdedse.org/pdf/work269.pdf

\section{CENTRE FOR DEVELOPMENT ECONOMICS}

DELHI SCHOOL OF ECONOMICS 


\title{
Local institutional structure and clientelistic access to employment: the case of MGNREGS in three states of India*†
}

\author{
Anindya Bhattacharya ${ }^{\ddagger}$ Anirban Kar $\S$ Alita Nandi $~$
}

December 21, 2016

\begin{abstract}
This work is a contribution, first, toward measuring and characterizing some features of rural clientelistic institutions and then toward exploring its impact on household access to an employment scheme (MGNREGS programme in India). We focus on patron-client relationship and the presence and intensity of that: i.e., on the nature and distribution of power in the rural society based on the data on personalized day-to-day interactions of the households residing in a village in economic, social and political spheres. We formulate a theoretical model to predict that the patrons use MGNREGS employment to secure political support of their respective clients. Using primary
\end{abstract}

*This project is funded by the European Union under the 7th Research Framework Programme (Theme SSH.2011.1), Grant acknowledgement number 290752. Bhattacharya also acknowledges an RIS fund from the University of York. Kar acknowledges additional financial and infrastructural support from Centre for Development Economics, Delhi School of Economics.

${ }^{\dagger}$ We are indebted to the comments and suggestions of several seminar and conference participants. Peter Lynn provided very useful help in our sample design. We acknowledge excellent research assistance from Vinayak Iyer, Amit Kumar, Mamta and Nishtha Sharma. Pramod Dubey and Sunil Kumar diligently monitored the household surveys. Of course, the errors are ours.

†Department of Economics and Related Studies, University of York

$\S$ Delhi School of Economics, University of Delhi, Delhi, India.

ฯISER, University of Essex 
data that we collected from 36 sample villages in the states of Maharashtra, Orissa and (Eastern) Uttar Pradesh in India we $(i)$ identify the presence of patron-client relationships with varying intensity, (ii) show that clients of elites have better access to MGNREGS employment than non-clients and (iii) a household in an elite village (i.e., a village where patron-client relationship is present), on average, has higher access to MGNREGS employment than a household in a nonelite village.

Keywords and Phrases: Clientelism, Network, MGNREGS

JEL Classification: O12; P47

\section{Introduction}

From onwards Acemoglu et al. [1], the role of institutions - the rules and conventions underlying socio-political interactions within a social unit - in affecting economic outcomes has been one major theme of study among economists specializing in problems of (under)development. A substantial body of this work has explored elite capture (for literature survey see [32] [33]), distortion of political accountability through lobbying and cronyism that impede the choice of pro-poor policies and divert resources to elites, as a possible cause of underdevelopment. Another channel of institutional distortion, clientelism, though quite pervasive in developing countries (seminal study by [37]) has come to focus only recently ([11], [4], [40], [39]). Clientelism refers to private transfers made by a section of elites (patron) to a section of poor and disadvantaged group (clients) as a means of securing their political support, while facing political competition from other sections of elites. Elite patrons control government, promote benefits to their clients in a quid pro quo arrangement but leaves governance largely in the interests of the elites. Ruling patrons favour this institutional distortion because private transfers to their clients are typically cheaper than public good provision and implementation of broad-based redistribution programme (such as land reform). Clients, however, receive only short term gains at the cost of long-run development. Moreover private transfers, which are inherently discretionary (rather than programmatic) create horizontal inequity and impede collective action by the poor which in turn reinforces the stability of 
clientelistic distortion [13].

Anderson et. al. [4] observes that 'A problem with assessing the clientelism hypothesis is the difficulty of observing it. Poor governance may arise for a number of reasons, and omitted unobserved factors may lead both to local elites running the political show and poor governance outcomes, without a causal link'. Moreover household surveys, directly asking questions on vote buying and political support, are likely to suffer severely from underreporting and misreporting. Thus work on clientelism, so far, have primarily relied on indirect evidences ${ }^{1}$. For instance, Anderson et. al. [4] uses variation in landholding and population of the dominant caste across villages in Maharashtra to predict when clientelism is more likely to arise. Bardhan and Mookherjee [11] relies on a dummy election conducted by the authors (as part of a household survey) to measure political support for the ruling party and relate it to private transfers received by a household. Stokes [38] also measures clientelism through reported instances of vote-buying in a household survey. Wantchekon [40] uses a field experiment in collaboration with political parties and found that clientelistic poll promises have significantly higher voter support than broadbased policies. Though these papers are extremely valuable in understanding the nature and impact of clientelism, all of them have primarily relied on indirect evidences and proxies of clientelistic practices.

Our paper aspires to fill this gap by providing a more direct account of clientelistic practices. We offer a novel conceptualization of clientelistic institutions that eases quantification and helps us to identify the variation and extent of clientelism across 36 surveyed villages in three states of India. Usually, in economics of institution, variations in institutions is conceptualized either as an outcome of the persistence of history (for instance [9] and [27]) or as an exogenously induced change in the system (e.g. [17]): examples being the existence or otherwise of bodies for local governance (called panchayat in India), existence or otherwise of a formal market within a village, rules of entitlement to land-ownership etc. We reckon that such conceptualization of institutions is more formal in nature. In the presence of clientelism, however, mere existence of a market does not entail freedom to trade. For instance [4] shows that clients depend on their patrons for access to trading network, which is controlled by the dominant caste. Similarly, mere existence of electoral bodies and rulebooks governing them does not imply the existence of

\footnotetext{
${ }^{1}$ There are many case studies, see [31] for an overview.
} 
democratic political processes (see for instance [30]). Therefore, we consider it to be more illuminating to measure the quality of institutions from data on the personalized day-to-day interactions of agents in the spheres of economy, society and politics. In his seminal paper on clientelism Scott [37] clearly demarcates this difference. 'Students of politics in the new states of Africa and Asia...have been struck by the relative weakness both of interest structures to organize demands and of institutionalized channels through which such demands, once organized, might be communicated to decisionmakers. The open clash of organized interests is often conspicuously absent during the formulation of legislation in these nations'. Machine politics (Scott uses this term for clientelism) instead is based on 'myriad of act that symbolized its accessibility, helpfulness and desire to work for the little man. The machine boss represented a patron of those at the bottom of social pyramid. Given its principal concern for retaining office, the machine was a responsive, informal context within which bargaining based on reciprocity relationships was facilitated'2 $^{\prime 2}$. Numerous case studies ([31], [28], [14]) also verify that clientelism depends on a dense network of economic-social-political interactions between patrons and clients.

We primarily conceptualize clientelism in the structure of multidimensional dependence in the spheres of economy, society and politics. We seek to explore whether such dependence is concentrated on a few entities dominating over a good many of households or whether this is distributed in a sufficiently diffuse manner. Moreover, our emphasis is on such dependence at local level, roughly at the level of the villages of interest and the neighbouring villages and town(s). Note that given our research goal, we were to introduce an identifier for localized institutional variations and single out some channels through which such variations should work.

The basis for constructing our institutional variation is the multidimensional directed network where the primary nodes are the sampled households

\footnotetext{
${ }^{2}$ Meiksins Wood [41] also emphasizes this difference while distinguishing between institutions. She observes '...only capitalism has a distinct economic sphere. This is so both because economic power is separate from political or military force and because it is only in capitalism that the market has a force of its own, which imposes on everyone, capitalists as well as workers, certain impersonal systemic requirements of competition, accumulation and profit-maximization...Although the sovereign territorial state was not created by capitalism, the distinctively capitalist separation of the economic and the political has produced a more clearly defined and complete territorial sovereignty than was possible in non-capitalist societies. At the same time, many social functions that once fell within the scope of state administration or communal regulation now belong to the economy.
} 
(HH hereafter) in each village. In our survey we gathered information on links the sample households have for help in spheres of day-to-day economic interactions (like whom the $\mathrm{HH}$ depends on for getting productive inputs, for selling of outputs if any, for loans etc), social interactions (like whom the $\mathrm{HH}$ approaches for advices on family matters and disputes, religious matters etc) as well as political ones (like whom the $\mathrm{HH}$ accompanies to political events if any etc). Using this information on multidimensional linkages of HHs on other HHs or entities ${ }^{3}$ we define various variants of consequent derived unidimensional dependence networks. The main underlying principle for constructing these dependence networks is that a node A is 'dependent', that is, has a directed edge on another node $\mathrm{B}$ if and only if $\mathrm{A}$ depends on $\mathrm{B}$ sufficiently strongly (in a well-defined manner the details of which are given in the following section) and the converse is not true. An entity with sufficiently many such dependents is called a local elite. A village having at least one local elite is called an elite village. We call a $\mathrm{HH}$ which is dependent on a local elite a client. We also construct another measure of local institutions: an index measuring the presence and intensity of patron-client dependence. This index of "elitism" is, of course, zero for villages with no local elites. We consider several variations of this main underlying idea.

Therefore, the institutional framework prevailing in a village, in our conceptualization, is not merely the result of the existence of any exogenously specified rule or body - it is an aggregate outcome of everyday interactions of the general population within the village. Moreover, unlike, e.g., in Banerjee et al. [8] we do not ask the respondents something like "who the important persons in the village are as per their impression' upfront. Rather, we derive the set of such 'important' entities from the revealed behaviour of the respondents themselves in several spheres of their actual lived experiences. We also do not rely on direct queries on vote buying and corruption, which to a large extent mitigate the problem of underreporting and misreporting.

We collected data from 36 villages in three states of India (Maharashtra, Orissa and the (eastern half) of Uttar Pradesh (UP)) using personal interviews at the $\mathrm{HH}$ level $^{4}$. One noticeable feature of what we call an elite village

\footnotetext{
${ }^{3}$ As service providers we considered non-household entities like church committees also, but when we have worked with local elites below, we confined our attention to human entities only.

${ }^{4}$ The survey first phase of the HH survey, covering mainly Orissa and Maharashtra, took place during March-April, 2013 and the second phase, covering mainly UP, took place in November-December, 2013. Details of the sample design can be found in Appendix C.
} 
is that such a village consists of a small number of persons (in our data we find them to be usually less than four or five) who have control over a number of households in terms of crucial economic dimensions (like providing credit or employment) and very often these same persons dominate in the spheres of social interactions as well as in political arenas around the village. In many cases the village sarpanch/pradhan (head) happens to be one such person. Very similar institutional features are corroborated by Ananthpur et al [3] in their micro-study in Karnataka (a state different from the ones from which we collected data).

To illustrate the underlying incentive structure of clientelistic distortion we construct a theoretical model. One of the channels through which private transfers to clients can be made is allocation of MGNREGS jobs ${ }^{5}$. Job allocation under this scheme to the different HHs in a village is controlled by the village panchayat and therefore, the local elites should have a good deal of power in determining who might get jobs under this scheme (a point emphasized in [3] as well). However a theoretical model of clientelism must resolve the issue of 'two-sided commitment' problem. How does the patron keep voters from reneging on the implicit deal where the patron distributes jobs and the client votes for the patron? On the other hand how do clients ensure that the patron continue providing favours once he is elected? Unlike pervious attempts $([4],[36])$ we do not rely on ethnic/caste ties to solve the commitment problem ${ }^{6}$. In our model, as in our conceptual framework, clients have potential multiple dependence on their patrons. A patron does not renege on his job allocation promises to protect his return from other channels. Clients also vote for their patron because they know that the patron has incentive to keep his job allocation promises. We show that clientelism through job allocation can persist even when landowners (distinct from patrons or elites) are opposed to MGNREGS implementation (because it increases agricultural wage). However, if either outside opportunities or countervailing power of landowners are sufficiently strong then clientelism breaks down in equilibrium.

\footnotetext{
${ }^{5}$ As is well known, the Mahatma Gandhi National Rural Employment Guarantee Scheme (MGNREGS) is supposed to provide a maximum of one hundred days of unskilled manual work to each rural household (at a government stipulated minimum wage) on demand. We refer to the official website of this schemehttp://www.nrega.nic.in/netnrega/home.aspx for details.

${ }^{6}$ Though ethnic/caste ties can indeed ease the commitment problem. Our empirical results also indicate this effect.
} 
Finally, we test some of our theoretical conjectures using our primary survey data. These are: $(i)$ clients of elites have better access to MGNREGS employment (measured as ever having received MGNREGS employment as well as the number of MGNREGS job-days in the last year) than non-clients and $(i i)$ a household in an elite village (village where patron-client relationship is present), on average, has higher access to MGNREGS employment than a household in a non-elite village. We find that indeed, with one standard deviation increase in intensity of 'elitism' in a village, probability that a $\mathrm{HH}$ has ever worked in MGNREGS, increases by 0.15 . Then we confine attention only to villages with local elites and find that in comparison to a non-client $\mathrm{HH}$, a client $\mathrm{HH}$ has $18 \%$ higher probability of getting MGNREGS jobs ever as well as 50\% more job-days in last 12 months. In other words, the kind of local institution that we measure seems to make a difference and the channel we have explored is one of the channels through which such an institution seems to affect development-related outcomes.

As we discuss in detail in Section 5 below, this work contributes not only to the literature on clientelism, but also to the bodies of literature on some other themes as well. These themes include measuring the value of connections or important nodes in the literature on networks, literature on factors determining MGNREGS job allocation etc. This paper does not directly address how clientelism may lead to long term underdevelopment we leave it for future research.

Section 2 contains the theoretical framework and analyses. Section 3 provides details of how we measure the local institutional characteristic. Section 4 presents our empirical analysis - this includes description of our data, main results and various robustness checks. We survey some important items of the relevant streams of literature in Section 5 and highlight the possible novelty and significance of our contribution in light of those. Figures and Tables are collected at the end.

\section{Theoretical Framework}

We construct a theoretical model of clientelism, where elites, who control socio-political institutions of the village, can allocate MGNREGS work to their clients as a tool for extending patronage, in return of their political support in election or village administration ${ }^{7}$. Such support can be useful

\footnotetext{
${ }^{7}$ See, [12] for some evidence. Our empirical results are presented in Section 5.
} 
for an elite to ward off potential political competition and challenges to rent extraction. Multiple channels of dependence help elites to solve the 'twosided' commitment problem. However, some channels of dependence could be unprofitable for the patrons and the resulting trade off determines extent of clientelism in equilibrium. Moreover, MGNREGS work provides labour market insurance to agricultural workers and can potentially increase the agricultural wage ${ }^{8}$. This squeezes agricultural profit and it is likely that large and middle peasants, who primarily live on agricultural profit, may oppose the implementation of MGNREGS (see [7]). Therefore equilibrium implementation of MGNREGS in a village (and hence the extent of clientelism) will depend on two opposite forces - landed peasants opposition to its implementation and local political elites favouring it as a channel for patronage provision - and their balance of power in local institution. Our model also gives rise to other interesting comparative statics insights. We predict that extent of clientelism has nonlinear relation with some development parameters. This is similar to Scott's [37] analysis - he claimed that clientelism proliferates at the initial phase of capitalist development and urbanization but further industrialization leads to decline of clientelism. We now formalize the above ideas.

\section{$2.1 \quad$ Model}

There are four groups of players; each group is homogeneous.

Politician-lender: Two identical politician-lenders, who compete in local election. They also lend money to agricultural workers.

Agricultural workers: Size of agricultural workers is normalized to 1. They are employed by the land owners. They also borrow money for consumption smoothing. Agricultural workers are the voters in local election.

Landowners: Landowners employ agricultural labourers. We assume that landowners are small in size and are outsiders, that is, they can not vote in local election. However they can still influence the election by taking up campaign in favour or against a politician-lender.

Moneylenders: They also lend money to agricultural workers. However moneylenders are not active players in this model.

We postpone the specification of payoffs and discuss the sequence of actions

\footnotetext{
${ }^{8}$ Empirical studies seem to suggest that there has been a rise in real casual laborer wages due to MGNREGS, with estimates ranging from $4 \%$ to $8 \%([26],[6])$.
} 
by the different players first.

The game is composed of three phases in the following sequence - credit arrangement for the workers, local election and operations in the labour market.

Credit market: Agricultural workers borrow money either from the politicianlenders or from the moneylenders. Borrowing is not a choice; all workers need to borrow 1 unit of money for consumption smoothing. As we shall see later that workers may (weakly) prefer to borrow from politician-lenders than moneylenders. This will be due to the possibility that politician-lender, while in power, can provide MGNREGS jobs to workers. However, we assume that when a worker is indifferent between the two options, he will borrow from a moneylender.

The game starts with the following decision by the politician-lenders. Two politician-lenders simultaneously choose the proportion of workers they want to lend money to, denoted by $s_{i}$ and $s_{j}{ }^{9}$. Those who don't get credit from politician-lender borrow from a moneylender. We assume that not only $s_{i}, s_{j}$ but the entire matching between politician-lenders/moneylenders and agricultural workers are observed by all agents.

Election: As we have mentioned already, landowners can not affect the outcome of the election directly. However they can provide campaign fund/effort to politician-lenders thereby having potential influence over the choice of $s_{i}$ and $s_{j}$. We ignore the collective action problem of the land owners. Therefore, for all practical purpose, we can assume that there is just one landowner. Campaign effort in support of politician-lenders $i$ and $j$ are denoted by $m_{i}$ and $m_{j}$ (which are non-negative real numbers) respectively.

Next, voters (that is workers) observe their individual 'loyalty shock'. This can be thought of as a measure of voter's non-pecuniary preference for politician-lender $i$ over politician-lender $j$ (perhaps resulting from candidate's position on non-economic issues $)^{10}$. Loyalty shock is a real number drawn

\footnotetext{
${ }^{9}$ Note that workers are identical and hence politician-lender can not discriminate between workers. If $s_{i}+s_{j}>1$ (size of the agricultural workers), then each get a proportional share. However, we shall make required assumptions to rule out such uninteresting corner solution.

${ }^{10}$ Note that if loyalty shocks are realized before the borrowing contracts are signed, a non-trivial matching problem between agricultural workers and political-lenders would arise. Our choice of timing will avoid this unnecessary complication, which is not central to our story.
} 
independently from a uniform distribution $\left[-\frac{1}{2}, \frac{1}{2}\right]^{11}$. We assume sincere voting (to be discussed below in greater detail). The loser of this election has no further role to play in our game.

Labour market: The labour market suffers from a moral hazard problem - a landowner cannot observe the effort chosen by a worker. However, landowner can identify those workers, who have borrowed from the incumbent and if required they are handed out a different contract from the rest of the workers. A worker chooses between two effort levels, high and low, with associated cost $e$ and 0 respectively. Probability of a successful harvest depends on effort choice; probability of success when high effort is chosen is denoted by $p_{e}$ while the probability of success under low effort is denoted by $p_{0}$. Naturally, $p_{e}>p_{0}$. More detail of labour contract follows.

Once the harvest is realized, incumbent decides the size of MGNREGS relief, that is, he chooses the fraction of population (denote it by $n$ ) which will receive MGNREGS work. To simplify our analysis, we assume that only workers whose harvest have failed are free to work under MGNREGS. There is no other restriction on eligibility for MGNREGS work; in particular identity of the lender is not an eligibility constraint. Sanctioned MGNREGS fund $B(n)$ is smooth, strictly increasing and strictly concave function ${ }^{12} ; B(0)=0$ and $B^{\prime}(0)=\bar{b}$. This implies that $\frac{B(n)}{n}$, per capita MGNREGS relief, is a decreasing in $n$ and $\lim _{n \rightarrow 0} \frac{B(n)}{n}=\bar{b}$.

We normalize the effort cost of workers on MGNREGS work to 0. MGNREGS payments and labour contracts are realized in the penultimate stage. Finally, workers make repayment and settle their credit contracts.

We describe the credit and labour contracts below.

Credit contracts: Both moneylenders and politician-lenders can only offer a limited liability contract and there is no collateral. Rate of interest is exogenously fixed. Recall that, both moneylenders and politician-lenders lend 1 unit. A worker, if his harvest is successful returns $r(r>1)$ to the lender; otherwise if harvest is not successful, returns 0. Politician-lender, while in power, however differs from moneylenders in his abilities to provide MGNREGS relief. If MGNREGS relief is provided, the politician-lender can

\footnotetext{
${ }^{11}$ Range can be easily generalized to $\left[-\frac{1}{2 \sigma}, \frac{1}{2 \sigma}\right]$ and our results won't change. Non zero mean may have non-trivial implication as it breaks the symmetry between two politicianlenders.

${ }^{12}$ Although MGNREGS wage is fixed, we assume that number of sanctioned work-days and hence the total fund is an increasing and concave function of $n$.
} 
extract his dues from the relief payment.

Labour contract: If a harvest is successful, it generates a revenue $q$ for the land owners, while failed harvest generates no revenue. We also assume that labour contracts have limited liability. Therefore a worker is paid $w$ if the harvest is successful and 0 otherwise. Naturally $w$ is a strategic choice by landowners and as noted above may vary across type of workers - those having credit contract with the incumbent and the rest. Workers also have an outside option to work in non-agricultural sector. The wage (net of effort cost) in non-agricultural sector is exogenously fixed at $\underline{w}$.

Payoffs of agents are as follows. All agents are risk-neutral.

Politician-lenders: Politician-lenders have two sources of income, namely, holding the political office and money lending. A Politician-lender earns a political rent $R$ if he wins the election and zero otherwise. We shall assume that $R$ is sufficiently large (Assumption A1). Politician-lenders also earn from the credit market. Recall that he lends 1 unit of money to an agricultural worker. With probability $p$ ( $p$ can be either $p_{e}$ or $p_{0}$, depending on worker's effort choice), $r$ is repaid by a worker. In case of a harvest failure (with probability $(1-p))$, repayment is as follows. If the politician-lender wins election and if he offers MGNREGS work to a borrower then $\min \left\{\frac{B(n)}{n}, r\right\}$ is recovered; otherwise he gets nothing. We shall assume $\lim _{n \rightarrow 0} \frac{B(n)}{n}=\bar{b}>r$, otherwise (given limited liability credit contract) there is no incentive for workers to seek MGNREGS jobs.

Suppose that politician-lenders can earn an amount $\rho$ by investing 1 unit outside the rural sector. We assume that opportunity cost of capital for politician-lender is higher than that for rural moneylenders, that is, $\rho \geq p_{e} r$ 13. Let $\bar{\rho}$ be the upper bound of $\rho$, thus $\rho \in\left[p_{e} r, \bar{\rho}\right]$.

Landowners: Recall that if a harvest is successful, it generates a revenue $q$ for the land owners, while failed harvest generates no revenue. A land owner maximizes his expected profit from production net of campaign effort cost, which is $\frac{1}{2}\left(m_{i}+m_{j}\right)^{2}$.

Agricultural workers: They earn from two sources - labour contract and MGNREGS jobs. As voters, workers engage in sincere voting. Following probabilistic voting models (for instance [23]), individual voting decision in our model will be influenced by following factors - expected payoff if candi-

\footnotetext{
${ }^{13}$ Those workers who have borrowed from a moneylender will choose high effort in equilibrium (to be illustrated later) and hence expected payoff of moneylenders is given by $p_{e} r$.
} 
date $i$ or $j$ wins $^{14}$, campaign influence and loyalty shock. Campaign influence in favour of candidate $i$ is given by $\alpha\left(m_{i}-m_{j}\right)$, where $\alpha$ denotes the effectiveness of campaign effort. The parameter $\alpha$ can also be interpreted as a measurement of clout of landowners. We assume $0 \leq \alpha \leq 1$.

\subsection{Results}

We are interested in symmetric subgame perfect Nash equilibrium of this game. As usual, we use backward induction to compute SPNE. Let us introduce a new notation at this point. Let $S_{i}$ and $S_{j}$ be the set the agricultural workers who have borrowed from political-lender $i$ and $j$ respectively. As mentioned before, measures of $S_{i}$ and $S_{j}$ are $s_{i}$ and $s_{j}$. Let $S_{M}$ be the rest of workers, that is those who have borrowed from a moneylender.

The last strategic choice is by the incumbent, who chooses $n$, fraction of population that will receive MGNREGS work. Without loss of generality, suppose that $i$ is the incumbent. By offering MGNREGS work to a worker in $S_{i}$ (that is those who have already borrowed from $i$ ), whose harvest has failed, $i$ recovers $\min \left\{\frac{B(n)}{n}, r\right\}$. Offering MGNREGS to a worker outside $S_{i}$ does not bring $i$ any extra payoff. Thus $i$ will offer MGNREGS work to only workers in $S_{i}$ and he will be indifferent between providing and not providing MGNREGS work to the rest. We follow equilibrium where only workers in $S_{i}$ receive MGNREGS work ${ }^{15}$. Since only those whose harvest has failed are eligible for relief, we have $n=s_{i}(1-p) ; p$ can be either $p_{0}$ or $p_{e}$. Thus a politician-lender, once elected, favours his own clients for MGNREGS work over the rest. Credit market 'interlinkage' thus helps politician-lenders to solve their commitment problem.

Next we shall compute optimal labour contracts. Since MGNREGS benefits act as an insurance in the case of a harvest failure, optimal contact for members of $S_{i}$ - when $i$ is the incumbent - can differ from the rest. Note that, if harvest fails, then, by our assumption of symmetric action choices, a member of $S_{i}$ gets MGNREGS relief worth $\frac{B\left(s_{i}(1-p)\right)}{s_{i}(1-p)}$. Due to limited liability, total repayment is capped at $\min \left\{\frac{B\left(s_{i}(1-p)\right)}{s_{i}(1-p)}, r\right\}$. Let us introduce a new notation:

\footnotetext{
${ }^{14}$ similar to payoff from candidates' policy position in a probabilistic voting model.

${ }^{15}$ A small effort cost (towards implementation of MGNREGS work) on the incumbent can also be incorporated to break this indifference. It won't change our result.
} 


$$
z(s)=\max \left\{\frac{B(s)}{s}-r, 0\right\} \text { for all } 0<s \leq 1 \text { and } z(0)=\bar{b}-r
$$

Note that $z(s)$ is continuous and weakly decreasing for all $s$. Let $\bar{s}$ be the smallest positive value of $s$ such that $z(s)=0$. We shall assume that $\bar{s} \leq$ $\frac{1}{2}\left(1-p_{e}\right)$ (Assumption A2).

First we find the optimal labour contract that will be offered to the members in $S_{i}$. The optimal contract will be designed in such a fashion that each member of $S_{i}$ finds it incentive compatible and individually rational to choose effort $e$. That is, when everyone else in $S_{i}$ except $k$ is expected to choose $e$, it should be optimal for $k$ to choose the same. This point is worth emphasizing because unlike the standard moral hazard model, utility of a worker here is dependent on other workers' choice through the volume of MGNREGS relief. Thus incentive compatibility constraint for members in $S_{i}$ is given by,

$$
\begin{array}{r}
p_{e}(w-r)+\left(1-p_{e}\right) z\left(s_{i}\left(1-p_{e}\right)\right)-e \geq \\
p_{0}(w-r)+\left(1-p_{0}\right) z\left(s_{i}\left(1-p_{e}\right)\right)
\end{array}
$$

First line of this inequality represents the expected utility of an agent in $S_{i}$ when he chooses $e$ : if a harvest is successful then he receives $w$ and repays debt $r$. Otherwise he receives MGNREGS relief worth $z\left(s_{i}\left(1-p_{e}\right)\right)$. Similarly, the second line represents the expected utility of an agent in $S_{i}$ when he chooses 0 effort while other workers choose $e$.

Individual rationality of agent in $S_{i}$ is given by,

$$
p_{e}(w-r)+\left(1-p_{e}\right) z\left(s_{i}\left(1-p_{e}\right)\right)-e \geq \underline{w}-r
$$

where $\underline{w}$ is the wage (net of effort cost) in non-agricultural sector. We assume that outside payment is large enough to cover for the loan repayment that is $\underline{w} \geq r$.

(ICW) implies that $w \geq\left[\frac{e}{p_{e}-p_{0}}+r+z\left(s_{i}\left(1-p_{e}\right)\right)\right]$ and (IRW) implies that $w \geq\left[\frac{1}{p_{e}}\left[\underline{w}+e-r-z\left(s_{i}\left(1-p_{e}\right)\right)\right]+r+z\left(s_{i}\left(1-p_{e}\right)\right)\right]$.

We now compute the optimal contract for agricultural workers who have not borrowed from the incumbent. Incentive compatibility and individual rationality constraints are given by

$$
\begin{gathered}
p_{e}(w-r)-e \geq p_{0}(w-r) \\
p_{e}(w-r)-e \geq \underline{w}-r
\end{gathered}
$$


Equation (ICO) implies that $w \geq\left[\frac{e}{p_{e}-p_{0}}+r\right]$ and Equation (IRO) implies that $w \geq\left[\frac{1}{p_{e}}[\underline{w}+e-r]+r\right]$. Following observations are immediate - $(i)$ if $w$ satisfies (ICW) then $w$ satisfies (ICO), (ii) if $w$ satisfies (IRO) then $w$ satisfies (IRW)

We partition our parameter space as follows. Recall that we have already assumed $\underline{w} \geq r$.

(i) $r \leq \underline{w} \leq \frac{e p_{0}}{p_{e}-p_{0}}+r$ : In this zone, in the optimal contract, incentive constraint will be binding for agricultural workers who are not client of the incumbent. This follows from comparing lower bound on $w$ under (ICO) and (IRO). Moreover, incentive constraint will also be binding for clients of the incumbent, because (ICW) $\Rightarrow(\mathrm{ICO}) \Rightarrow(\mathrm{IRO}) \Rightarrow$ (IRW) (first and third ' $\Rightarrow$ ' follows from our earlier observations).

(ii) $\frac{e p_{0}}{p_{e}-p_{0}}+\bar{b}>\underline{w}>\frac{e p_{0}}{p_{e}-p_{0}}+r($ Recall that $\bar{b}>r)$ : Since $\underline{w}>\frac{e p_{0}}{p_{e}-p_{0}}+r$, individual rationality constraint, that is (IRO), is binding for workers who are not client of the incumbent, while (ICW) is binding for clients of the incumbent.

(iii) $\underline{w} \geq \frac{e p_{0}}{p_{e}-p_{0}}+\bar{b}$ : In this zone, individual rationality constraints are binding for all agents. That is both (IRW) and (IRO) are binding. This follows from comparing lower bound on $w$ under (ICW) and (IRW).

We are now ready to state our main result. Under (A1) $R$ is sufficiently $\operatorname{large}^{16}$ and $(\mathrm{A} 2) \bar{s} \leq \frac{1}{2}\left(1-p_{e}\right)$,

Proposition 1 For every value of $\rho \in\left[p_{e} r, \bar{\rho}\right]$, we can find a cutoff on $\underline{w}$, denoted by $\underline{w}^{\star}$, such that for all $\underline{w}<\underline{w}^{\star}$ there exists an interior symmetric equilibrium where both politician-lender have a clientele. Clients are more likely to vote for their patrons and only those workers who have borrowed from the incumbent get MGNREGS work. For all $\underline{w} \geq \underline{w}^{\star}$ there is no clientelism in equilibrium. The cutoff is characterized as follows. If $\rho \leq \frac{1}{2} r\left(1+p_{e}\right)$ then the cutoff is independent of $\rho$ and coincides with zone (iii), that is $\underline{w}^{\star}=\frac{e p_{0}}{p_{e}-p_{0}}+\bar{b}$. For $\rho>\frac{1}{2} r\left(1+p_{e}\right)$, cutoff $\underline{w}^{\star}$ is a function of $\rho$ and belongs to zone (ii), that is, $\frac{e p_{0}}{p_{e}-p_{0}}+r<\underline{w}^{\star}<\frac{e p_{0}}{p_{e}-p_{0}}+\bar{b}$.

Here we provide a quick sketch of the proof, Appendix A contains the full detail. In zone (iii), both individual rationality constraints (IRW) and (IRO) are binding. Thus insurance of MGNREGS job does not play any role and

\footnotetext{
${ }^{16}$ See Appendix A for a lower bound on $R$.
} 
given our assumption that indifferent workers will borrow from moneylenders, we can rule out clientelistic equilibrium. Therefore when outside option for workers is high enough, clientelism will disappear, irrespective of the opportunity cost of capital. In zone $(i)$, workers prefer to borrow from the politician-lenders because MGNREGS job provides insurance. Since a politician-lender does not renege on his commitment after winning an election, clients also prefer to vote for their respective patron. As a consequence, probability of winning the election increases in $s . z\left(s\left(1-p_{e}\right)\right)$. A politicianlender has an incentive to increase $s$ as far as it increases winning probability through $s . z\left(s\left(1-p_{e}\right)\right)$. However, an increase in $s$ may increase his losses in the credit market. These two opposing forces determine the client size in equilibrium. Intuition for zone $(i i)$ is similar to zone $(i)$ but has an important difference. Since individual rationality constraint (IRO) is binding in this zone, extent of MGNREGS insurance benefit and hence winning probability decreases with an increase in outside opportunity $\underline{w}$. Thus we obtain a cutoff on $\underline{w}$ above which clientelism disappears in equilibrium. Naturally, higher the opportunity cost of capital, lower is the cutoff.

Proposition 1 also illustrates the impact of outside opportunities on equilibrium outcome. Let us now add how the clout of landowners $(\alpha)$ play an important role. Observe that in zone $(i)$ (similar argument in zone (ii)) incentive constraints are binding for all workers, which means clients of the incumbent get $\left[\frac{e}{p_{e}-p_{0}}+r+z\left(s\left(1-p_{e}\right)\right)\right]$ in case of a successful harvest while others get only $\left[\frac{e}{p_{e}-p_{0}}+r\right]$. Thus landowners have to pay an extra wage bill of $s . z\left(s\left(1-p_{e}\right)\right)$ and consequently they campaign for the politician-lender with lower s.z $\left(s\left(1-p_{e}\right)\right)$ value. Naturally, given such tradeoff, effectiveness of campaign parameter $\alpha$ affect the equilibrium client size. However, unlike outside opportunities parameters $\rho$ and $\underline{w}$, clout parameter $\alpha$ does not have a linear relation with equilibrium outcome. If $\rho$ is sufficiently small, credit market gains tempt the politician-lenders to expand the client size although it reduces winning probability. Here an increase in the clout of landowners make credit market gains more attractive and increases client size. The opposite happens when opportunity cost of capital $\rho$ is high; equilibrium client size decreases in $\alpha$. These results are reminiscent of Scott's [37] scheme of institutional development - he argued that clientelism increases at the initial phase of capitalist development and urbanization but further industrialization leads to decline of clientelism. Our results are also consistent with the historical 
pattern of institutional changes in India. While land ownership gradually shifted from landlords to rich farmers and increased their influence in rural society (particularly after green revolution), outside opportunities for investment and employment have remained relatively stagnant. These economic preconditions along with electoral competition and increasing possibility of rent extraction through local governance may have led to proliferation of clientelism in India.

Proposition 2 compiles our comparative statics results; a proof can be found in Appendix A.

Proposition 2 Let $s^{\star}$ be the equilibrium size of clientele in symmetric equilibrium. (a) Everything else remaining the same an increase in $\underline{w}$ decreases $s^{\star}$. (b) Everything else remaining the same an increase in $\rho$ decreases $s^{\star}$. (c) An increase in $\alpha$ increases $s^{\star}$ when $\rho \leq \tilde{\rho}$ and decreases $s^{\star}$ otherwise. In zone $(i), \tilde{\rho}=\frac{1}{2}\left(1+p_{e}\right) r$ and in zone $(i i), \tilde{\rho}<\frac{1}{2}\left(1+p_{e}\right) r$.

We end this section with a few comments on our theoretical structure and assumptions. First, we chose to model the agricultural labour market as a principal-agent problem rather than wage contract. We admit that it appears to contradict ground realities. However the principal-agent set up can be an useful short hand for capturing (possibly performance based) complexities that can not be explained by a spot market. Here are a few such examples: agricultural wages typically depend on type of task - number of days a household gets employment in a particular type of task vary across households; landowners delay payment or extend advance payments at their discretion etc. Next, our model uses MGNREGS jobs as a possible channel of patronage provision. However it must be noted that it is one of many possible channels - we don't intend to imply that clientelism is a result of MGNREGS programme or that it will disappear if MGNREGS is rescinded. Finally, we repeat that our model (and empirical results) is not intended to capture welfare implication of clientelism; therefore we ignore its impact on public good provision, accountability of elected representatives etc., in this paper. 


\section{Localized Institution: Dependence, Elites, Clients}

Conceptual formalization and quantification of 'localized dependence' is quite rare in Economics. Our formalization is based on the following core components. First, dependence is embedded in day to day activities, both economic and socio-political. Access to inputs of production, market access for products, dispute resolution and participation in political process are a few examples of such activities. The second aspect of dependence is personalized interaction. This is distinct from formal institutional interactions. Borrowing from banks, approaching police station for dispute resolution etc. are instances of formal institutional interactions, while borrowing from informal lenders, approaching local political leaders for dispute resolution are personalized interactions. These two aspects together imply that the dependence structure we are exploring is essentially localized in nature. Finally, high concentration and interlinkage of dependence links are indicators of stronger localized power.

Recall that the primitive in this context in our set-up are the households' links for getting help in social, economic and political spheres. If $\mathrm{HH} M$ receives an economic, social or political service from $\mathrm{HH} N$, then $\mathrm{HH} M$ is said to have an outgoing service link to household $N$. We also classify outgoing service links into two groups - crucial and non-crucial - based on their relative importance. This classification is based on our perception and judgment. For instance, a service-link of seeking advice for resolution of household disputes is categorized as non-crucial whereas seeking advice for profession-related disputes is categorized as crucial. Admittedly, this classification is subjective but not arbitrary. The full list of services, classified as $(i)$ economic/social/political and (ii) crucial/non-crucial can be found in Table 2.1. Since we ask survey households whether such services are reciprocated, we also have data on outgoing links from Household $N$ to Household $M$. In case, Household $M$ is also part of our sample, we have an independent verification of such claims (we could not make such cross-verification in general (hough $)^{17}$.

Note that, in our network data, there can be multiple such service-links between two nodes: i.e., households. First we aggregate these to a single

\footnotetext{
${ }^{17}$ In case of mismatch, though such instances are rare, claims of the household which has received the service is accepted.
} 
dimension, called dependence-connection. To capture relative strength of dependence relation, we classify dependence-connections into three types. Type $A$ : HH $M$ is said to have Type $A$ outgoing dependence-connection to HH $N$ only if $M$ has exactly one crucial outgoing service-link to $N$. A single non-crucial link is unlikely to be an indicator of clientelistic relation.

Type $B$ : HH $M$ is said to have Type $B$ outgoing dependence-connection to HH $N$ only if $M$ has at least two outgoing links to $N$ that are of similar kind, either all economic or all social or all political. This captures interlinkages in received services .

Type $C$ : HH $M$ is said to have Type $C$ outgoing connection to $\mathrm{HH} N$ only if (i) $M$ has at least two outgoing links to $N$ and (ii) not all of them are similar kind (economic/social/political) of services. This captures interlinkage in different spheres of daily/usual interactions.

Since (clientelistic) dependence should be conceived as an asymmetric power relation (in contrast to a reciprocal relationship like friendship), we exclude all bilateral, mutual outgoing dependence-connections from our network. Directed cycles of higher length do not appear in our data. Thus $\mathrm{HH} M$ is said to be dependent on $\mathrm{HH} N$ if $(i) \mathrm{HH} M$ has an outgoing dependence-connection of at least one type to $\mathrm{HH} N$ and $(i i) \mathrm{HH} N$ does not have any outgoing dependence-connection to HH $M$. This completes our description of (weighted, directed, single dimensional) network of dependence relations. In Diagram 2.1 we plot outgoing links of one of our survey villages.

Next we use network data to identify the presence and pattern of clientelist network of sampled villages. If a clientelist network is present then it would be characterized by patrons and clients. It is expected that clients will be dependent on patron(s) for various (often interlinked) services and a number of clients will be dependent on a patron. Thus a 'hub and spoke' type network is expected to emerge in such villages. To this end, we define a patron, called elite as follows. If more than five percent of the sampled households are dependent on a household $\mathrm{X}$ then $\mathrm{X}$ is potentially an important patronage-provider in the village and is called an elite. This captures concentration of dependence in our network data. A household which is dependent on at least one elite is called a client. Any household, which is neither a client nor an elite will be called non-client. In Diagram 2.2 we plot dependence-connection network of two villages, one with presence of elites and another without.

A couple of comments are due at this stage. First, since we have not done census for each of the sample villages, we only see the village depen- 
dence networks partially. We can not rule out presence of additional hubs in dependence network and our elite identification could be incomplete. Thus it is possible that some households in our sample who justifiably can be called clients are getting incorrectly categorized as non-clients ${ }^{18}$. In some regression specification, we use degree of dependence as an alternative to client/nonclient categorization. Degree of dependence of a Household $M$ is the total number households on which $M$ is dependent, irrespective of whether the service provider is an elite or not. Formally, degree of dependence of Household M is defined as $D_{M}=\mid\{N \mid \mathrm{HH}$ M is dependent on HH N $\} \mid$. Second, other than mutual dependence, higher order directed cycles are rare in our village network. Therefore centrality measures (see for instance [24]) are somewhat superfluous for our purpose and we choose to stick to the simple definition of elites described above.

Finally, we define a weighting scheme to complete our description of dependence network. Interlinkage of service provision in multiple types of spheres is assigned the maximum weight, followed by interlinkage in one sphere and that by only one crucial dependence-connection.

$W_{M N}=3:(i) \mathrm{HH} M$ is dependent on $\mathrm{HH} N$ and (ii) $M$ has Type $C$ outgoing dependence-connection to $N$.

$W_{M N}=2$ : $(i)$ HH $M$ is dependent on $\mathrm{HH} N$ and ( $\left.i i\right) M$ has Type $B$ outgoing dependence-connection to $N$.

$W_{M N}=1$ : $(i) \mathrm{HH} M$ is dependent on $\mathrm{HH} N$ and (ii) $M$ has Type $A$ outgoing dependence-connection to $N$.

otherwise, $W_{M N}=0$

To capture pervasiveness of patron-client relation in a village we use the following index, nclscore $=\frac{1}{n} \sum_{\{i \mid i}$ is a client of elite ${ }_{j\}} W_{i j}$, where $n$ is the sample size and $W_{i j}$ is described as above. Note that the we are adding weights only over links where $i$ is a client of an elite $j$. Intuitively, we ignore all dependence links where the service provider is not a hub of the dependence network. Naturally, those villages where there is no such hub, that is there is no elite, have nclscore $=0$. We use nclscore as an index for measuring 'degree of elitism' in a village. Table 2.2 provides the frequency distribution of nclscore by state.

In our sample, 13 villages have no-elites and 23 villages have at least one elite. We have identified 54 elites and 511 clients in 23 villages. Table 2.3

\footnotetext{
${ }^{18}$ Our derived network variable being somewhat complicated, we do not have any correction for sampled links (as in [16]).
} 
documents a few characteristics of elites and clients. Here caste, religion and occupational information of elites are based on household reports. Table 2.3 underscores the asymmetric nature of dependence links. Most of the elites are either upper caste or OBC whereas most clients are SC, ST and OBC. Elites are mostly engaged in farming and business whereas almost half of the clients are labourers. Our dependence network is quite different from other social networks (for example friendship) that have homophily as a primary feature.

\section{Empirical Analysis}

\subsection{Data Description}

In this section we provide a short description of the survey data used and detailed definitions of the dependent and explanatory variables. MGNREGS provides a maximum of hundred days of unskilled manual work to each rural household at a government stipulated minimum wage. We consider two indices of access to MGNREGS employment; (i) number of days a household had MGNREGS employment the year prior to our survey (to be precise, within 12 months before our survey) and (ii) whether a household has ever participated in MGNREGS work since its inception. We call these indices wdaysnum and wdaysever respectively. We have wdaysever data for our entire sample but wdaysnum only for the first phase of our survey, that is for Maharashtra and Orissa. This is due to a change in survey question in second phase where instead of asking the exact number of days worked last year, we used intervals. So, we excluded UP villages from the estimation of wdaysnum models. Table 3.1 and Diagram 3.1 provide descriptive statistics of MGNREGS employment for our sample by client status. Note that $67 \%$ of all client households have worked in MGNREGS at least once, whereas only 44\% non-client households have ever worked in MGNREGS. In last 12 months prior to our survey, clients received about 20 days of MGNREGS work, while non-clients got 13.5 days of work, on average.

MGNREGS work is supposed to be available on demand. However, it has been widely documented that the program is not demand-driven in practice (see, e.g., Dutta et al (2015; [21])). In any case, to control for demand side factors we use various household and village characteristics in our regressions. Below we provide the list of explanatory variables, other than the network- 
related ones which we have already discussed in the previous section.

Caste/Religion of a household: As in India caste and/or religion of a $\mathrm{HH}$ can influence access and opportunities, we control for caste/religion in our models. We classify the various castes/religion into five categories. Hindus are divided into three categories 'Lower' (including SC/ST/NT), 'OBC' and 'Upper' (General and Brahmin). If a household has reported jati name instead of the above categories we match it with administrative lists of SC,ST,NT and OBC lists for the corresponding states. For religion, we use self-reported religion. Since apart from Hindu and Muslim, there are very few households of other religions, we use 'Muslim' as our fourth category and club all other religion as 'Other'.

We use several variables to capture the economic condition of a household. These are, land ownership, an index of non-land assets and occupation. Amount of land owned by a household is measured in acres. Non-land asset for a household is measured by aggregating indicators of 6 types of assetitems so that the score for each household varies between 0 and 6 . These six items are ownership of a pucca house for residence in the village, (additionally) owning a house in a town or a city, possessing television, possessing some kind of automobile, having expensive bed (palang) in the premises and owning trees.

Households reported on its main occupation from a list of six occupations: farming, artisans or have a factory, shop-keeper or running a business of some type, working as labourers, working at an office for a salary, collecting and selling forest products, other. Most commonly reported categories were farming and working as an agricultural or non-agricultural labourer, followed by business/factory/ production unit and/or salaried position; to a small extent occupations like collection of forest product and somewhat casual types of jobs as working as a priest etc. We classify the main occupation (selfreported by the $\mathrm{HH}$ ) into two categories: stable and other. Stable occupation includes running a business/factory/ production unit and/or salaried position in some organization.

Further, availability of informal insurance is captured through a remittance from outside variable. This is a dummy, which takes the value 1 if someone living outside the village sends money to the household.

Since MGNREGS work involves only unskilled manual labour, presence of less-educated but able-bodied members in a household who may not get an opportunity to work in the formal sector, can be an important demand side factor. We use number of household members between age 16 and 60 
years and educated up to secondary level at most, as an indicator for this determinant. Naturally, education is also important for awareness of a household about its legal rights as well as government schemes. We use the level of the maximum education among all the members of a household as the corresponding explanatory variable. This can take three values: up to higher secondary education, undergraduation or equivalent degrees and above undergraduation.

Apart from its position in clientelistic network, a household may have other formal and informal channels through which it may exert influence on collective decisions. Membership of formal institutional bodies such as political parties and local government, capacity to organize collective actions, can earn a household a larger share of MGNREGS work compared to others. We use three dummy variables to capture these channels. First, socio-political influence, which takes the value 1 if a household has at least one member who either is (was) a member of local government or is a member of a political party/labour union. We also use two more dummy variables to capture the 'voice' of a household in community matters. advice given takes the value 1 if a household mediates in community disputes, while experience with local administration takes the value 1 if a household has experience of visiting administrative offices or other such formal institutions.

We also control for some village level characteristics likely to affect our dependent variables. Some of these were collected in the short village survey we conducted simultaneously with the household survey. Some other items of data have been taken from the Census of India, 2011 or other governmental sources. Village characteristics used in our regressions are as follows: distance to town (distance to the nearest town measured in $\mathrm{km}$ ), average rainfall (average rainfall in the neighborhood of the village measured in $\mathrm{mm}$ ), irrigation (the net sown area of the village which is irrigated) and percentage labour (percentage of households in the village for which agriculture and/or working as agricultural labour is the main occupation).

A list of all variables used in our estimations along with a short description for each can also be found in Appendix B.

Our sample consisted of all villages for estimation of wdaysever and 24 villages in Maharashtra and Orissa for wdaysnum. While the interviews were conducted with heads of household, in a few cases, when the $\mathrm{HOH}$ was not present another household member responded on their behalf. We checked the age and sex of the respondent and excluded the cases where the respondent is female and less than 18 years of age as they may not have 
been well-informed about the household. We also excluded the few elite HHs (and rare cases where an elite is dependent on a $\mathrm{HH}$, for which we call the latter a super-elite) from our sample. Finally, we excluded all $\mathrm{HH}$ for which any of the dependent or explanatory variables was missing. Additionally, restrictions are imposed for testing Hypothesis (ii) (see below).

\subsection{Empirical Results}

In this section, we use our measure of institution as an identifier of balance of power in surveyed villages and test a couple of our theoretical predictions. Villages, where dependence network is pervasive and elites are present, we expect a small group to exercise control over resources and local government. Whereas absence of elites and lack of dependence relations are indicative of diffused power structure, which is consistent with a control of relatively larger group of rich and middle peasants.

We have already mentioned that MGNREGS work is usually planned and executed by the local government and the bureaucratic personnel. Although peoples' participation in planning through gram sabhas is recommended and work allocation is supposed to be demand-driven, in practice, common villagers have very little control over the process (see, for example, [25]). A deserving household, in practice, is not guaranteed to receive MGNREGS work - MGNREGS card (say unlike the BPL card, for subsidized food grains) is not an entitlement but is only used to keep record. Moreover, since it was supposed to be demand driven, there is also no mandated rationing rule for allocation of MGNREGS work to households. It is quite possible that some households are offered MGNREGS work every year while others are denied. These features, along with the perishable nature of the benefit (unlike, say one-time grants); make MGNREGS jobs highly conducive for clientelistic transfer.

Our theoretical framework led us to the following hypotheses

(i) On average, a resident is likely to get more MGNREGS work in a village where patron-client relation is more pervasive.

(ii) In villages where patron-client relation is pervasive, a client is likely to get more MGNREGS work in comparison to a non-client

Hypothesis $(i)$ :

In Table 5.1, we report the results of OLS regression with wdaysever/ 
wdaysnum as the dependent variables and the degree of elitism, nclscore, as the main explanatory variable of interest. The regression equation has the following form

$$
y_{i j}=\alpha_{0}+\alpha_{1} \text { nclscore }_{j}+\alpha_{2} X_{i j}+\alpha_{3} Z_{j}+\varepsilon_{i j}
$$

Where $y_{i j}$ is the MGNREGS employment variable for household $i$ in village $j$; nclscore $_{j}$ measures the degree of elitism in village $j, X_{i j}$ represents the household-level controls and $Z_{j}$ represents the village-level controls. The errors are clustered at the village level. We find that nclscore has a positive and significant impact on wdaysever. A unit increase in nclscore in a village increases the probability of a household having ever worked in MGNREGS by 0.34 . By replacing nclscore by other variants, such as, a dummy for elite villages (which takes value 1 if a village has at least one elite, and 0 otherwise) does not change the direction of association.

However, for wdaysnum this association is not significant, although the corresponding coefficients still remain positive. One explanation of this slightly different behaviour of wdaysnum and wdaysever may be as follows. Note that wdaysnum index is based on last 13 months, whereas wdaysever captures the entire period since the introduction of MGNREGS. It is possible that elites are distributing MGNREGS work to client households across years, so some client households receive MGNREGS work in year $t$, some in $t+1$ and so on. This is very likely, particularly because of the fact that total MGNREGS work received by a village (as documented in Table 3.1), on average, is quite low.

We verify the above results with hierarchical modeling (see, e.g., [15]). The level 1 is that of the households in each village and the higher level is that of the villages. The results remain exactly the same. See Table 5.2 and Table 5.3.

\section{Hypothesis (ii):}

For analyzing the impact of being a client household on getting MGNREGS employment, we restrict our sample to the elite villages (there are 23 such villages), that is to those villages with at least one elite (and hence clients). This restriction is required because we want to measure the impact of being a client in securing MGNREGS jobs in comparison to being a non-client within the same institutional environment of an (elite) village. Moreover, to ensure that the village has some non-negligible implementation of the MGNREGS programme, we restrict our regression to those villages for which wdaysever 
(similarly for wdaynum) takes non-zero values for at least 5 households. This restricts our sample to 22 villages for wdaysever and 10 villages for wdaysnum. The basic regression equation has the following form

$$
y_{i j}=\beta_{0}+\beta_{1} \text { client }_{i j}+\alpha_{2} X_{i j}+\alpha_{3} Z_{j}+\varepsilon_{i j}
$$

where client $_{i j}$ is a dummy variable which takes value 1 if households $i$ of village $j$ is a client and 0 otherwise. The errors are clustered at the village level. We also use state dummy to control state-specific effects.

Client dummy has positive and significant effect on both wdaysever and wdaysnum. See Model 1 in Table 5.4 and Model 1 in Table 5.5 for results of wdaysever and wdaysnum respectively. Clients are $8 \%$ more likely to work in MGNREGS ever compared to non-clients. Note that about $44 \%$ nonclient household in these villages have ever worked in MGNREGS - that is clients are $18 \%$ more likely to get work than the rest. Clients also got more than 6 extra days of work compared to non-clients in 13 months prior to our survey. Non-clients, on average, received 13 days of work in this period, which means clients got $50 \%$ more work than non-clients. Since for many households wdaysnum is zero (note that for non-client households median is 0), we run TOBIT regression, which also shows positive and significant client effect (see Table 5.6).

Model 2 in each of the above Tables is obtained by replacing our main variable of interest, client dummy variable by degree of dependence. The positive effect of clientelism on wdaysever persists but for wdaysnum, degree of dependence does not have significant positive effect any more. There are two important differences between client dummy and degree of dependence. First, as was already mentioned, we may fail to identify some elites because we use sampling rather than census. In this respect degree of dependence is a more reliable index than client dummy. However client dummy captures the importance of being dependent on an elite compared to being dependent on not-so-influential person. To understand this difference more clearly, we run the basic regression, where households are divided into three categories - households which are not dependent on any other household (of any type), household which are dependent (of some type) on another household - but is not dependent on an elite, households which are dependent on an elite that is clients. These results are available presented in Model 3 of Table 5.4 and Table 5.5. Whereas the second and third categories, that is, dependent but not client and client, have significant and positive effect on wdaysever; only client has positive and significant effect on wdaysnum. 
Next we reckon that allocation of MGNREGS work being a politicoadministrative decision at the village level, a local elite with experience/connection with formal political activities might have greater influence in securing such jobs to their clients. In Model 4 of the above regression tables, we divide the households in three categories, non-client, client of an elite who either is/was part of local government or is a member of a political party, and client of an elite with no political connection/affiliation. We find our conjecture to be true - clients of political elites have significantly higher wdaysever compared to non-clients while clients of non-political elites are not significantly different from non-clients. However in wdaysnum we find similar positive significant effect on both types of clients (political and non-political).

Further it has been observed that in rural India horizontal linkages through caste results in economic gains (e.g. [34]) for a household. Therefore, we check whether a client of the same caste as the village pradhan/sarpanch gets significantly more MGNREGS jobs. Here we divide the households into four groups based on the Cartesian product of the following characteristics clients/non clients, same caste/different caste as that of the panchayat pradhan (head of village administration). Model 5, in Table 5.4 and Table 5.5, show that only clients who are of same caste as panchayat pradhan get significantly higher wdaysnum and wdaysever compared to the (omitted category) non-clients who are of different caste.

\subsection{Further Results: Checking for Robustness and Al- ternative Explanations}

Results in the previous section suggest that clientelism affects both the availability and allocation of MGNREGS jobs. However, alternative explanations, a priori, could be consistent with our findings. In this section, we try to rule out such possibilities.

First, it is possible that although elites are providing MGNREGS work to their clients but it is merely due to name-recognition rather than any underlying political-economic calculations. It has been observed that clientelistic patronage tend to use perishable consumables, such as temporary jobs, to retain patron's control (see [11]) over the clients. In contrast, a one-time lump-sum favour is useless as a commitment device. If biased allocation of MGNREGS work is merely due to name recognition, then we shall expect a similar pattern for one-time welfare benefits like BPL cards and assistance 
through Indira Awas Yojana. We run regressions, which are otherwise identical to our previous analysis, on one-time benefits. We find that client-status indicating variables are not significant any more. This is consistent with clientelism explanation. See Table 6.1 for the detailed result.

Next, it is also possible that awareness rather than clientelism is driving our results. Clients, being connected with elites, perhaps, are better informed about MGNREGS work compared to non-clients. To look into this possibility, we use an index of awareness about the MGNREGS scheme as a dependent variable and run a regression, exactly similar to our basic specification (Equation 2). We find that client dummy is not significant; in fact, coefficient of client dummy is negative. See Table 6.2 for detail.

Next, as a robustness check we used alternative measures of the degree of elitism and its effectiveness. The first alternative proxy for nclscore we use is the average number of dependence connections in the village. Table 6.4 shows that the result is exactly along the same direction as for nclscore. Next, the theoretical model predicts that if the clout of big farmers-those who cultivate relatively larger chunks of land by employing agricultural labourers-go up, then that would reduce the effectiveness of clientelism and, in turn, its impact on MGNREGS allocation. Toward this end, we first measure the proportion of the sampled households in a village who are big farmers. We considered three definitions of a big farmer: (i) bfscore1: HH whose main occupation is farming and who owns land that is greater than a certain threshold, (ii) bfscore2: $\mathrm{HH}$ whose main occupation is farming and who owns land that is greater than a certain threshold and who employs agricultural labourers more than a certain threshold, and (iii)bfscore3: HH whose main occupation is farming and who owns land that is greater than a certain threshold or who employs agricultural labourers more than a certain threshold, The land threshold is the maximum of the village average and 2 acres. The agricultural labourers' threshold is the maximum of the village average and 10. Our regression results, reported in Table 6.4, reinforces the finding that an increase in the degree of elitism in a village increases a HH's access to MGNREGS employment.

Finally, our key household-level explanatory variable - client dummy- is potentially endogenous. There can exist unobservable household characteristics, such as household preferences, which may induce a household both to have dependence connection with influential people around a village as well as be prone for taking up workfare jobs. To take care of that we introduce the following binary variable, called landlord heritage as an instrument for client- 
status. The variable landlord heritage takes the value 1 if the household is found to have any outgoing service link (and not necessarily any dependence connection) to a household which has been reported to be of landlord status or royal origin. The underlying idea is that such a link, is likely to be correlated with client status but is unlikely to affect MGNREGS allocation because landlord heritage links predates MGNREGS scheme. We understand that our instrument is not satisfactory, it may have similar endogeneity problem as the client dummy. We find that Hausman-Wu test with respect to this IV does not reject the hypothesis that our explanatory variable client status is exogenous. However, with this IV, client status is not significant any more although the effect of client status on MGNREGS outcomes still remains positive. This result of 2SLS is presented in Table 6.3.

\section{Existing Literature and Our Contribution}

As we mentioned in the Introduction, this work contributes to several streams of research apart from political economy of clientelism. Below we mention the significant works related to this work and remark on what new we introduce to the existing literature.

Impact of institutions on development-related outcomes

We repeat that one of our central goals is to emphasize studies in 'measuring' institutions not in terms of some exogenously given characteristics but endogenously, by using data on day-to-day interactions as the primitive. In this respect our work is different from apparently similar works like Acemoglu et al. [2] which looks into the impact of connection with 'elites'. 'Elites' in their case are historically given. Moreover, unlike, for example, as in Goldstein and Udry [22] we do not measure the impact of having power only in the sphere of formal politics (more on this, especially in the context of allocation of MGNREGS jobs, below). We conceptualize the exercise of power (and the reciprocal idea of dependence) as dominance in several dimensions.

Value of connections or important nodes

A set of literature exists on the value or impact of connections: very notable among them Bandeira et al. [10], Munshi and Rosenzweig [34]. Our contribution, naturally, falls also into this terrain of research. We find that it is not that merely connections matter but connection with (endogenously) powerful entities matters. Banerjee et al. [8] is especially notable in our context as it 
also explores the role of 'powerful' nodes. However, the kinds of day-to-day socio-economic relations they took as primitive are more or less 'symmetric': i.e., links for their study represent 'friendship'. In contradistinction, we, by our research question, explicitly concentrate on 'asymmetric' power relation.

\section{Allocation of MGNREGS jobs}

MGNREGS, being the largest of such workfare programmes ever, has attracted a lot of analysis. While much of the existing analyses deal with the results of this intervention (e.g., [26], [29]) there is a small set of literature dealing with factors affecting allocation of NREGS jobs. The work closest to ours in this regard is Das [18]. Studying a few villages in a district in West Bengal (a state in India) he found evidence of the positive impact of political clientelism in securing such jobs -'households, which are politically active and supporters of the local ruling political party, are more likely to receive the benefits in terms of participation, number of days of work and earnings from the program'. Dey and Bedi [19] reinforce such a finding (again for West Bengal): they find that 'during the period covered by our survey, the right populist party - Trinomool Congress (TMC) ruled Gram Panchayats (GP) promoted more political clientelism through distributing MGNREGS work than did the Communist Party of India-Marxist (CPIM) or Left GPs' (however, they also report that this effect is attenuating over time).

Our study generalizes such findings in several dimensions. First, we find such evidence for a larger sample spreading over three states of India with quite diverse economic and political histories. Next, we find that not only dependence on elites with formal political power entails in securing better MGNREGS job-prospects, but also, elites with no such formal political positions are also able to extend clientelism in form of such jobs. This, we repeat, seems to be in conformity with Ananthpur et al [3] that traditionally dominant households, even without formal positions in political office, can still influence decisions of local governments. Here we also mention the recent work by Dey and Imai [20] which seems complementary to our findings. Dey and Imai find that increased participation in MGNREGS positively affects getting of local credit at the household level. That may precisely be owing to the possibility that at least a section of such creditors, being local elites, provide more jobs to their clients to ensure smooth repayment of debt which is in conformity to our findings. Our work also partially reinforce the findings in a growing literature on the presence of corruption in the MGNREGS programme (e.g., [35]). 


\section{References}

[1] Acemoglu, D., S. Johnson and J. Robinson, (2001); The Colonial Origins of Comparative Development: An Empirical Investigation; American Economic Review, Vol. 91, No. 5, 1369-1401.

[2] Acemoglu, D., T. Reed and J.A. Robinson (2014); Chiefs: Economic Development and Elite Control of Civil Society in Sierra Leone; Journal of Political Economy, Vol. 122, No. 2, 319-68.

[3] Ananthpur, K., K. Malik and V. Rao (2014); The anatomy of failure: An ethnography of a randomized trial to deepen democracy in rural India; Mimeo, World Bank, Report No. WPS6958.

[4] Anderson, S., P. Francois and A. Kotwal (2015); Clientelism in Indian Villages; American Economic Review; Vol. 105, No. 6, 1780-1816.

[5] Anderson, S., P. Francois, A. Kotwal and A. Kulkarni (2015); Implementing MGNREGS: 'One Kind of Democracy'; Economic and Political Weekly, Vol. 50, Issue 26-27, 44-48.

[6] Azam, M. (2012); The Impact of Indian Job Guarantee Scheme on Labor Market Outcomes: Evidence from a Natural Experiment; IZA DP No. 6548 .

[7] Bandyopadhyay D. (2007); A betrayal!; Mainstream Weekly, Vol XLV, No 47; https://www.mainstreamweekly.net/article423.html

[8] Banerjee, A., A. G. Chandrasekhar, E. Duflo and M. O. Jackson (2013); The Diffusion of Microfinance; Science, Vol. 341, Issue 6144.

[9] Banerjee, A. and L. Iyer (2005); History, Institutions, and Economic Performance: The Legacy of Colonial Land Tenure Systems in India; American Economic Review, Vol 95, No. 4, 1190-1213.

[10] Bandeira, O., I. Barankay and I. Rasul (2009); Social Connections and Incentives in the Workplace: Evidence from Personnel Data; Econometrica, Vol. 77, Issue 4, 1047-94.

[11] Bardhan, P. and D. Mookherjee (2012); Political Clientelism and Capture: Theory and Evidence from West Bengal; Mimeo, http://people.bu.edu/dilipm/wkpap/clientcapaug2012f.pdf 
[12] Bardhan, P., S. Mitra, D. Mookherjee and A. Nath (2014); Changing Voting Patterns in Rural West Bengal: Role of Clientelism and Local Public Goods; Economic and Political Weekly, Vol. 49, Issue 11, 54-62.

[13] Bardhan, P., S. Mitra, D. Mookherjee and A. Sarkar (2009); Local Democracy and Clientelism: Implications for Political Stability in Rural West Bengal, Economic and Political Weekly, Vol. 44, Issue 9, 46-58.

[14] Brun, D. A. and L. Diamond (2014); Clientelism, Social Policy, and the Quality of Democracy; edited volume, John Hopkins University Press.

[15] Bryan, M. L. and S. P. Jenkins (2013); Regression Analysis of Country Effects Using Multilevel Data: A Cautionary Tale; ISER Working Paper Series, https://www.iser.essex.ac.uk/research/publications/workingpapers/iser/2013-14

[16] Chandrashekhar, A. G. and R. Lewis (2011); Econometrics of Sampled Network; Mimeo, http://stanford.edu/ arungc/CL.pdf

[17] Chattopadhyay, R. and E. Duflo (2004); Women as Policy Makers: Evidence from a Randomized Policy Experiment in India; Econometrica, Vol. 72, No. 5, 1409-43.

[18] Das, U. (2015); Does Political Activism and Affiliation Affect Allocation of Benefits in the Rural Employment Guarantee Program: Evidence from West Bengal, India; World Development, Vol. 67, 202-17.

[19] Dey, S. and A. Bedi (2015); Falling Clientelism or Regime Change? Benefit Incidence of India's Employment Guarantee Programme A Panel data Analysis from West Bengal, India; Mimeo.

[20] Dey, S. and K. Imai (2015); Workfare as 'Collateral': The case of the National Rural Employment Guarantee Scheme (NREGS) in India; Mimeo, http://www.rieb.kobe-u.ac.jp/academic/ra/dp/English/DP2014-27.pdf

[21] Dutta, P., R. Murgai, M. Ravallion and D. van de Walle (2015); Empowering Poor People through Public Information? Lessons from a Movie in Rural India; Journal of Public Economics; Vol. 132, pp. 13-22.

[22] Goldstein, M. and C. Udry (2008); The Profits of Power: Land Rights and Agricultural Investment in Ghana; Journal of Political Economy, Vol. 116, No. 6, 981-1022. 
[23] Grossman, G. M. and E. Helpman (1996); Electoral Competition and Special Interest Politics; The Review of Economic Studies, Vol. 63, No. $2,265-286$.

[24] Herings, P.J., G. van der Laan and D. Talman (2005); The Positional Power of Nodes in Digraphs; Social Choice and Welfare, Vol. 24, 439-454.

[25] Himanshu, A. Mukhopadhyay and M. R. Sharan (2015); The National Rural Employment Guarantee Scheme in Rajasthan: Rationed Funds and their allocation across villages; Economic and Political Weekly, Vol. 15, Issue No. 6.

[26] Imbert, C. and J. Papp (2015); Labor Market Effects of Social Programs: Evidence from India's Employment Guarantee; American Economic Journal: Applied Economics, Vol. 7, No. 2, 233-63.

[27] Iyer, L. (2010); Direct versus Indirect Colonial Rule in India: Longterm Consequences; Review of Economics and Statistics, Vol. 92, No. 4, 693-713.

[28] Jeffrey, C. (2002); Caste, Class, and Clientelism: A Political Economy of Everyday Corruption in Rural North India; Economic Geography, Vol. 78, No. 1, 21-41.

[29] Khanna, G. and L. Zimmerman (2015); Guns and Butter? Fighting Violence with the Promise of Development; Mimeo, IZA DP No. 9160.

[30] Khemani, S. (2015); Buying Votes versus Supplying Public Services: Political Incentives to Under-invest in Pro-poor Policies; Journal of Development Economics, Vol. 117, 84-93.

[31] Kitschelt H. and S. Wilkinson (2007), Patrons, Clients and Policies: Patterns of Democratic Accountability and Political Competition, Cambridge University Press.

[32] Mansuri G. and V. Rao (2011); Localizing Development: Does Participation Work?; World Bank Policy Research Report.

[33] Mookherjee, D. (2014); Accountability of Local and State Governments in India: An Overview of Recent Research; Indian Growth and Development Review, Vol. 7 Issue 1, 12 - 41 
[34] Munshi, K. and M. Rosenzweig (2016); Networks and Misallocation: Insurance, Migration, and the Rural-Urban Wage Gap; American Economic Review, Vol. 106, No. 1, 46-98.

[35] Niehaus, P. and S. Sukhtankar (2013); Corruption Dynamics: The Golden Goose Effect; American Economic Journal: Economic Policy, Vol. 5, No. 4, 230-269.

[36] Robinson J. and T. Verdier (2003); The Political Economy of Clientelism, The Scandinivian Journal of Economics, Vol. 115, No. 2, 260291.

[37] Scott, J. (1969); Corruption, Machine Politics and Political Change; The American Political Science Review, Vol. 63, No. 4, 1142-1158.

[38] Stokes S. (2005); Perverse Accountability: A Formal Model of Machine Politics with Evidence From Argentina; American Political Science Review, Vol. 99, No. 3, 315-325.

[39] Vicente, P. C. and L. Wantchekon (2009); Clientism and Vote Buying: Lessons from Field Experiments in West Africa; Oxford Review of Economic Policy, Vol. 25, No. 2, 292-305.

[40] Wantchekon L. (2003); Clientelism and Voting Behavior: Evidence from a Field Experiment in Benin; World Politics, Vol. 55, No. 3, 399-422.

[41] Wood, E. M. (2003); Empire of Capital; Verso. 


\section{Tables and Diagrams}

Table 2.1: Classification of services by type

\begin{tabular}{lll}
\hline \multicolumn{1}{c}{ Services } & $\begin{array}{c}\text { Economic, Social } \\
\text { or Political }\end{array}$ & $\begin{array}{l}\text { Crucial or Non } \\
\text { crucial }\end{array}$ \\
\hline Lease-in land or sharecropping & Economic & Crucial \\
Purchase input of production & Economic & Not crucial \\
Sale output & Economic & Crucial \\
Getting employment & Economic & Crucial \\
Getting informal credit & Economic & Crucial \\
Paying bribe for governmental welfare services & Economic & Crucial \\
Assistance for welfare & Political & Crucial \\
Getting information about MGNREGS & Economic & Not crucial \\
Household related dispute mediation & Social & Not crucial \\
Employment related dispute mediation & Social & Crucial \\
$\begin{array}{l}\text { Guidance on political matter (like whom to vote or } \\
\text { accompanying to political meetings or rallies) }\end{array}$ & Political & Crucial \\
Guidance on religious matter & Social & Not crucial \\
\hline
\end{tabular}

Table 2.2: State-wise frequency distribution of NCL_SCORE

\begin{tabular}{lccc}
\hline \multicolumn{1}{c}{ State } & NCL_SCORE $=\mathbf{0}$ & $\mathbf{0}<$ NCL_SCORE $\leq \mathbf{0 . 2}$ & NCL_SCORE $>\mathbf{0 . 2}$ \\
\hline Maharashtra & 6 & 2 & 4 \\
Orissa & 3 & 4 & 5 \\
Eastern UP & 4 & 2 & 6 \\
\hline
\end{tabular}


Table 2.3: Elite and client characteristics

\begin{tabular}{lcc}
\hline & Elite & Client \\
\hline Caste and religion & & \\
$\quad$ Upper caste & $49 \%$ & $8 \%$ \\
OBC & $31 \%$ & $44 \%$ \\
$\quad$ Other caste and religion & $20 \%$ & $48 \%$ \\
Occupation & & \\
$\quad$ Farming or Business & $96 \%$ & $56 \%$ \\
$\quad$ Other & $4 \%$ & $44 \%$ \\
Mean of land ownership in acres & 3.9 & 1.3 \\
SD of land ownership in acres & 3.9 & 2.0 \\
Mean of non-land assets (wealth indicator) & 3.4 & 1.6 \\
SD of non-land assets (wealth indicator) & 1.3 & 1.2 \\
\hline
\end{tabular}

Table 3.1: Summary statistics of MGNREGS days worked by client status

\begin{tabular}{llll}
\hline & Client & $\begin{array}{l}\text { Non-client } \\
\text { (Elite villages } \\
\text { only) }\end{array}$ & $\begin{array}{l}\text { Non-client } \\
\text { (all villages) }\end{array}$ \\
\hline $\begin{array}{l}\text { Proportion ever did MGNREGS work } \\
\text { MGNREGS days worked in the last 13 }\end{array}$ & $67 \%$ & $44 \%$ & $41 \%$ \\
months & & & \\
$\quad$ Mean & 19.8 & 13.3 & 13.5 \\
Median & 15.0 & 0 & 0 \\
SD & 23.0 & 23.6 & 24.5 \\
\hline
\end{tabular}


Table 5.1: Estimated coefficients and p-values from models of MGNREGS days worked in the last 12 months and ever worked for MGNREGS estimated using OLS and LPM, respectively

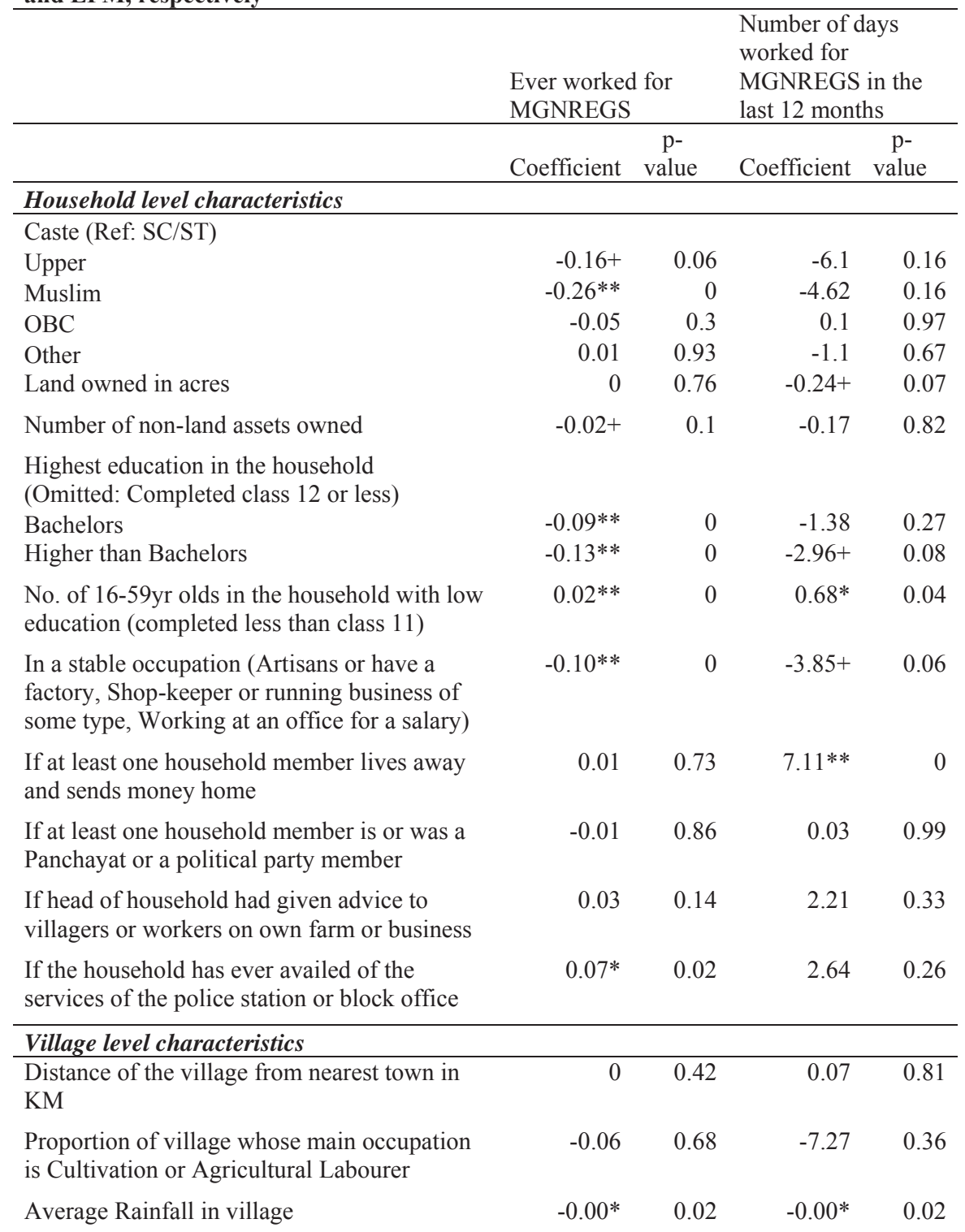




\begin{tabular}{lrrrr} 
Fraction of net sown area irrigated & $-0.17+$ & 0.07 & -3.23 & 0.56 \\
\hline State (Omitted: Maharashtra) & & & & \\
Odisha & 0.09 & 0.22 & 2.81 & 0.51 \\
Uttar Pradesh & 0.06 & 0.5 & & \\
NclScore & $0.34 * *$ & 0 & 6.14 & 0.12 \\
Constant & $0.49^{* *}$ & 0 & $13.68+$ & 0.09 \\
\hline No. of Observations & 3344 & & 2231 & \\
R-squared & 0.252 & & 0.113 & \\
\hline Robust standard errors & & & & \\
$+\mathrm{p}<0.10^{*} \mathrm{p}<0.05 * * \mathrm{p}<.01$ & & & &
\end{tabular}

Table 5.2: Estimated coefficients and p-values from a multi-level model of ever worked for MGNREGS

\begin{tabular}{|c|c|c|c|c|}
\hline & $\begin{array}{c}\text { Random } \\
\text { Intercept } \\
\text { Model }\end{array}$ & & $\begin{array}{c}\text { Random } \\
\text { Slopes } \\
\text { Model } \\
\end{array}$ & \\
\hline & Coefficient & $\mathrm{p}$-value & Coefficient & $\mathrm{p}$-value \\
\hline \multicolumn{5}{|l|}{ Household level characteristics } \\
\hline \multicolumn{5}{|l|}{ Caste (Ref: SC/ST) } \\
\hline Upper & $-0.22 * *$ & 0 & $-0.21 * *$ & 0 \\
\hline Muslim & $-0.20 * *$ & 0 & $-0.20 * *$ & 0 \\
\hline $\mathrm{OBC}$ & $-0.10 * *$ & 0 & $-0.10 * *$ & 0 \\
\hline Other & -0.07 & 0.19 & -0.07 & 0.17 \\
\hline Land owned in acres & $-0.01 *$ & 0.03 & $-0.01 *$ & 0.04 \\
\hline Number of non-land assets owned & $-0.01 *$ & 0.02 & $-0.01 *$ & 0.02 \\
\hline \multicolumn{5}{|l|}{$\begin{array}{l}\text { Highest education in the household } \\
\text { (Omitted: Completed class } 12 \text { or less) }\end{array}$} \\
\hline Bachelors & $-0.05^{*}$ & 0.02 & $-0.05^{*}$ & 0.02 \\
\hline Higher than Bachelors & $-0.10 * *$ & 0 & $-0.09 * *$ & 0.01 \\
\hline $\begin{array}{l}\text { No. of } 16-59 y \text { olds in the household with } \\
\text { low education (completed less than class } 11 \text { ) }\end{array}$ & $0.03 * *$ & 0 & $0.03 * *$ & 0 \\
\hline $\begin{array}{l}\text { In a stable occupation (Artisans or have a } \\
\text { factory, Shop-keeper or running business of } \\
\text { some type, Working at an office for a salary) }\end{array}$ & $-0.09 * *$ & 0 & $-0.10 * *$ & 0 \\
\hline $\begin{array}{l}\text { If at least one household member lives away } \\
\text { and sends money home }\end{array}$ & 0 & 0.93 & 0 & 0.82 \\
\hline $\begin{array}{l}\text { If at least one household member is or was a } \\
\text { Panchayat or a political party member }\end{array}$ & 0 & 0.87 & 0.01 & 0.81 \\
\hline
\end{tabular}




\begin{tabular}{|c|c|c|c|c|}
\hline $\begin{array}{l}\text { If head of household had given advice to } \\
\text { villagers or workers on own farm or business }\end{array}$ & $0.04 *$ & 0.02 & $0.04 *$ & 0.02 \\
\hline $\begin{array}{l}\text { If the household has ever availed of the } \\
\text { services of the police station or block office }\end{array}$ & $0.06^{* *}$ & 0 & $0.06 * *$ & 0 \\
\hline \multicolumn{5}{|l|}{ Village level characteristics } \\
\hline $\begin{array}{l}\text { Distance of the village from nearest town in } \\
\text { KM }\end{array}$ & 0 & 0.26 & 0 & 0.15 \\
\hline $\begin{array}{l}\text { Proportion of village whose main occupation } \\
\text { is Cultivation or Agricultural Labourer }\end{array}$ & -0.01 & 0.96 & 0.01 & 0.94 \\
\hline Average Rainfall in village & $-0.00+$ & 0.09 & 0 & 0.27 \\
\hline Fraction of net sown area irrigated & $-0.18+$ & 0.1 & $-0.20+$ & 0.05 \\
\hline \multicolumn{5}{|l|}{ State (Omitted: Maharashtra) } \\
\hline Odisha & 0.1 & 0.32 & 0.07 & 0.44 \\
\hline Uttar Pradesh & 0.06 & 0.49 & 0.02 & 0.85 \\
\hline NclScore & $0.34 * *$ & 0 & $0.34 * *$ & 0 \\
\hline Constant & $0.46^{* *}$ & 0.01 & $0.44 * *$ & 0.01 \\
\hline No. of Observations & 3344 & & 3344 & \\
\hline $\operatorname{lns} 1 \_1 \_1$ & -1.77 & . & -3.63 & . \\
\hline lnsig_e- & -0.95 & . & -0.96 & 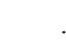 \\
\hline $\operatorname{lns} 1 \_1 \_2$ & & & -1.64 & ${ }^{\circ}$ \\
\hline atr1_1_1_2 & & & -0.75 & ${ }^{\circ}$ \\
\hline No. of Observations & 3344 & & 3344 & \\
\hline
\end{tabular}

$+\mathrm{p}<0.10 * \mathrm{p}<0.05 * * \mathrm{p}<.01$

Table 5.3: Estimated coefficients and p-values from a multi-level model of MGNREGS days worked in the last 12 months

\begin{tabular}{lrrrr} 
& \multicolumn{2}{c}{$\begin{array}{c}\text { Random Intercept } \\
\text { Model }\end{array}$} & \multicolumn{2}{c}{$\begin{array}{c}\text { Random Slopes } \\
\text { Model }\end{array}$} \\
\hline Household level characteristics & Coefficient & p-value & Coefficient & p-value \\
\hline Caste (Ref: SC/ST) & & & & \\
Upper & & & & \\
Muslim & $-3.07+$ & 0.1 & $-3.07+$ & 0.1 \\
OBC & -2.01 & 0.52 & -1.56 & 0.6 \\
Other & -0.27 & 0.8 & -0.21 & 0.85 \\
Land owned in acres & -2.26 & 0.34 & -2.18 & 0.36 \\
Number of non-land assets owned & $-0.28+$ & 0.05 & $-0.39^{*}$ & 0.03 \\
Highest education in the household & -0.29 & 0.37 & -0.26 & 0.41
\end{tabular}


(Omitted: Completed class 12 or less)

Bachelor

$\begin{array}{rrrr}0.66 & 0.55 & 0.67 & 0.55 \\ -1.1 & 0.54 & -1.11 & 0.53 \\ 0.97 * * & 0 & 0.97 * * & 0 \\ & & & \\ -1.68 & 0.18 & -1.61 & 0.19\end{array}$

No. of 16-59yr olds in the household with low education (completed less than class 11)

In a stable occupation (Artisans or have a

If at least one household member is or was a

If head of household had given advice to

business

If the household has ever availed of the

0.02

$2.53 *$

services of the police station or block office

\begin{tabular}{lrrrr}
\hline Village level characteristics & & & & \\
\hline $\begin{array}{l}\text { Distance of the village from nearest town in } \\
\text { KM }\end{array}$ & 0.19 & 0.29 & 0.24 & 0.14 \\
$\begin{array}{l}\text { Proportion of village whose main occupation } \\
\text { is Cultivation or Agricultural Labourer }\end{array}$ & -8.73 & 0.27 & -9.45 & 0.2 \\
Average Rainfall in village & & & & \\
Fraction of net sown area irrigated & 0 & 0.19 & 0 & 0.17 \\
\hline State (Omitted: Maharashtra) & -2.19 & 0.69 & -0.8 & 0.88 \\
Odisha & & & & \\
NclScore & 3.47 & 0.46 & 2.92 & 0.51 \\
Constant & $5.81+$ & 0.09 & 5.25 & 0.1 \\
\hline No. of Observations & 10.22 & 0.27 & 9.5 & 0.27 \\
lns1_1_1 & 2231 & & 2231 & \\
lnsig_e & 2.02 &. & -1.07 &. \\
lns1_1_2 & 2.85 &. & 2.85 &. \\
atr1_1_1_2 & & & 2.08 &. \\
\hline
\end{tabular}

$+\mathrm{p}<0.10 * \mathrm{p}<0.05 * * \mathrm{p}<.01$ 
Table 5.4: Estimated coefficients from a model of ever worked for MGNREGS among households in elite villages; estimated using LPM

\begin{tabular}{|c|c|c|c|c|c|}
\hline \multirow{2}{*}{ State (Ref: Maharashtra) } & Model1 & Model2 & Model3 & Model4 & Model5 \\
\hline & & & & & \\
\hline Odisha & $-0.15 * *$ & $-0.15 * *$ & $-0.14 *$ & $-0.15 * *$ & $-0.15^{* *}$ \\
\hline Uttar Pradesh & $-0.30 * *$ & $-0.29 * *$ & $-0.28 * *$ & $-0.30 * *$ & $-0.28 * *$ \\
\hline NclScore & $0.18^{*}$ & $0.17^{*}$ & $0.18 *$ & $0.17^{*}$ & $0.17 *$ \\
\hline $\begin{array}{l}\text { Client status (Ref: Non- } \\
\text { client) }\end{array}$ & & & & & \\
\hline Client & $0.08 *$ & & & & \\
\hline $\begin{array}{l}\text { Client status (Ref: non- } \\
\text { client) }\end{array}$ & & & & & \\
\hline $\begin{array}{l}\text { Client but not of political } \\
\text { elite }\end{array}$ & & & & 0.04 & \\
\hline Client of political elite & & & & $0.09 *$ & \\
\hline $\begin{array}{l}\text { Client status } \\
\text { (Ref: non-client, not } \\
\text { dependant) }\end{array}$ & & & & & \\
\hline Dependant but not client & & & $0.16 * *$ & & \\
\hline Client & & & $0.13 * *$ & & \\
\hline $\begin{array}{l}\text { Client status (Ref: non- } \\
\text { client, Panchayat Pradhan of } \\
\text { different caste) }\end{array}$ & & & & & \\
\hline Non-client, Panchayat & & & & & 0.03 \\
\hline Pradhan of same caste & & & & & \\
\hline $\begin{array}{l}\text { Client, Panchayat Pradhan } \\
\text { of different caste }\end{array}$ & & & & & 0.05 \\
\hline $\begin{array}{l}\text { Client, Panchayat Pradhan } \\
\text { of same caste }\end{array}$ & & & & & $0.14+$ \\
\hline Number of dependents & & $0.09 * *$ & & & \\
\hline No. of Observations & 2083 & 2083 & 2083 & 2083 & 2032 \\
\hline R-squared & 0.202 & 0.221 & 0.219 & 0.203 & 0.201 \\
\hline $\begin{array}{l}\text { Robust standard errors } \\
+\mathrm{p}<0.10 * \mathrm{p}<0.05 * * \mathrm{p}<.01 \\
\# \text { This sample excludes those } \\
\text { households who have a } \\
\text { missing value on Panchayat } \\
\text { Pradhan caste }\end{array}$ & & & & & \\
\hline
\end{tabular}


Table 5.5: Estimated coefficients from a model of MGNREGS days worked in the last 12 months among households in elite villages; estimated using OLS

\begin{tabular}{lrrrrr}
\hline & Model1 & Model2 & Model3 & Model4 & Model5 \\
\hline State (Ref: Maharashtra) & & & & & \\
Odisha & $8.36^{*}$ & $8.60^{*}$ & $8.50^{*}$ & $8.44^{*}$ & $7.49^{*}$ \\
NclScore & $11.49^{*}$ & $13.97^{*}$ & $11.65^{*}$ & $12.45^{* *}$ & $10.07^{*}$ \\
$\begin{array}{l}\text { Client status (Ref: Non- } \\
\text { client) }\end{array}$ & & & & & \\
Client & $6.34+$ & & & & \\
\hline
\end{tabular}

Client status (Ref: non-

client)

Client but not of political

$15.31+$

elite

Client of political elite

Client status

(Ref: non-client, not

dependant)

Dependant but not client $\quad 0.72$

Client

$6.57+$

Client status (Ref: non-

client, Panchayat Pradhan of

different caste)

Non-client, Panchayat

Pradhan of same caste

Client, Panchayat Pradhan

Client, Panchayat Pradhan

of same caste

Number of dependents

No. of Observations

$\mathrm{R}$-squared

1.35

Robust standard errors

$+p<0.10 * p<0.05 * * p<.01$

\# This sample excludes those households who have a missing value on Panchayat Pradhan caste 
Table 5.6: Estimated coefficients from a model of MGNREGS days worked in the last 12 months; estimated using TOBIT

\begin{tabular}{lrr}
\hline & Model 1 & Model 2 \\
\hline State (Ref: Maharashtra) & -2.88 & -7.18 \\
Odisha & $15.13+$ & 20.73 \\
NclScore & & \\
Client status & $12.72 *$ & 0.79 \\
(Ref: Non-client) & & 1.43 \\
Client & & $54.96^{*}$ \\
Odisha X NclScore & 2.31 \\
Odisha X Client & & $-58.18^{* *}$ \\
Client X NclScore & 910 & 910 \\
Odisha X Client X NclScore & & \\
\hline No. of Observations & $37.09 * *$ & $36.52 * *$ \\
R-squared & & \\
Sigma & & \\
\hline Robust standard errors & & \\
$+\mathrm{p}<0.10 * \mathrm{p}<0.05 * * \mathrm{p}<.01$ & &
\end{tabular}

Table 6.1: Estimated coefficients from a model of receiving any of the three one-time benefits (BPL card, Old-age pension, Indira Awas Yojana) among households in elite villages estimated using $L P M$

Estimation sample of ever worked for MGNREGS
Estimation sample of number of days worked for MGNREGS (in the last 12 months)

State (Ref:

Maharashtra)

Odisha

$-0.08$

$-0.09$

UP

0.02 0.04

NclScore

Client status

(Ref: Non-client)

Client

Number of observations $-0.03$

R-squared

2083

0.074

0.079


Table 6.2: Estimated coefficients from a model of

MGNREGS awareness among households in

elite villages estimated using LPM

State (Ref: Maharashtra)

Odisha $0.55^{*}$

UP 0.33

NclScore $\quad 0.26$

Client status

(Ref: Non-client)

Client $\quad-0.03$

Number of observations 1505

R-squared $\quad 0.256$

Table 6.3: Estimated coefficients from models of MGNREGS days worked in the last 12 months and ever worked for MGNREGS; estimated using 2SLS

\begin{tabular}{|c|c|c|c|c|}
\hline & $1^{\text {st }}$ stage & $2^{\text {nd }}$ stage & $1^{\text {st }}$ stage & $2^{\text {nd }}$ stage \\
\hline & Client & $\begin{array}{l}\text { Ever worked } \\
\text { for } \\
\text { MGNREGS }\end{array}$ & Client & $\begin{array}{l}\text { Number of } \\
\text { days worked } \\
\text { for } \\
\text { MGNREGS } \\
\text { in the last } 12 \\
\text { months }\end{array}$ \\
\hline \multicolumn{5}{|l|}{ Household level characteristics } \\
\hline \multicolumn{5}{|l|}{$\begin{array}{l}\text { Caste/Religion (caste and religion of head of household) } \\
\text { (Ref: SC/ST) }\end{array}$} \\
\hline Upper & -0.01 & $-0.14+$ & $0.09+$ & 1.14 \\
\hline Muslim & 0.04 & $-0.27 * *$ & $0.42 * *$ & $-5.99+$ \\
\hline $\mathrm{OBC}$ & $0.04 *$ & -0.02 & $0.13 * *$ & 1.25 \\
\hline Other & -0.01 & -0.01 & 0.01 & -0.26 \\
\hline Land owned (Total rural land by the household in acres) & 0 & 0 & 0.00 & $-0.83 * *$ \\
\hline $\begin{array}{l}\text { Non-land assets index } \\
\text { Maximum education in household (maximum level of } \\
\text { education among all household members) } \\
\text { (Ref: Completed class } 12 \text { or less) }\end{array}$ & -0.01 & -0.01 & -0.02 & -0.54 \\
\hline Bachelors & -0.01 & $-0.08 *$ & -0.03 & 1.6 \\
\hline Higher than Bachelors & -0.01 & $-0.15^{*}$ & 0.03 & $-8.13 * *$ \\
\hline $\begin{array}{l}\text { Potential workers (number of household members with } \\
\text { education below secondary level and aged between } 16 \text { and } 60 \text { ) }\end{array}$ & 0 & $0.03 * *$ & 0.00 & $1.84 * *$ \\
\hline $\begin{array}{l}\text { Stable occupation ( } 1 \text { if head of household running a } \\
\text { business/factory/production unit and/or salaried position in some } \\
\text { organization) }\end{array}$ & $-0.06 * *$ & $-0.10^{*}$ & -0.10 & $-6.32+$ \\
\hline
\end{tabular}




\begin{tabular}{|c|c|c|c|c|}
\hline $\begin{array}{l}\text { Remittance received ( } 1 \text { if if someone living outside the } \\
\text { village sends money to the household) }\end{array}$ & -0.03 & -0.01 & -0.02 & $3.92 * *$ \\
\hline $\begin{array}{l}\text { Socio-political influence ( } 1 \text { if a member of household is/was } \\
\text { panchayat pradhan/member of local government/ position holder of } \\
\text { political party, union) }\end{array}$ & -0.01 & 0.01 & 0.02 & -0.39 \\
\hline $\begin{array}{l}\text { Advice given ( } 1 \text { if household members mediate in community } \\
\text { disputes) }\end{array}$ & $0.01 * *$ & $0.07 *$ & 0.01 & 4.57 \\
\hline $\begin{array}{l}\text { Experience with local services ( } 1 \text { if any household } \\
\text { member has experience of dealing with police, court, administration) }\end{array}$ & 0.06 & $0.07 *$ & $0.11+$ & 3.15 \\
\hline \multicolumn{5}{|l|}{ Village level characteristics } \\
\hline $\begin{array}{l}\text { Distance to town (distance of the village to the nearest town in } \\
\text { kilometres) }\end{array}$ & 0 & 0 & 0 & $-0.75 * *$ \\
\hline $\begin{array}{l}\text { Percentage Agriculture (proportion of households in the } \\
\text { village whose main occupation is agriculture or working as an } \\
\text { agricultural labourer) }\end{array}$ & 0.02 & 0 & 0.14 & $15.53 *$ \\
\hline Average Rainfall (in the village) & 0 & $-0.00 * *$ & 0 & $-0.04 * *$ \\
\hline $\begin{array}{l}\text { Irrigation (Proportion of sown area in the village which is } \\
\text { irrigated) }\end{array}$ & 0.02 & $-0.23 *$ & -0.03 & $-10.77 * *$ \\
\hline \multicolumn{5}{|l|}{ State (Ref: Maharashtra) } \\
\hline Odisha & 0.04 & $-0.15^{* *}$ & -0.02 & $9.06 * *$ \\
\hline Uttar Pradesh & -0.03 & $-0.30 * *$ & & \\
\hline NclScore & $0.36^{* *}$ & $0.17 *$ & $0.43 * *$ & $12.77 * *$ \\
\hline \multicolumn{5}{|l|}{ Client status (Ref: Non-client) } \\
\hline Client & & 0.09 & & 5.36 \\
\hline IVoutlinkLLR=1 & $0.28 * *$ & & $0.24 * *$ & \\
\hline Constant & -0.08 & $0.93 * *$ & -0.27 & $56.94 * *$ \\
\hline No. of Observations & 2062 & 2062 & 904 & 904 \\
\hline R-squared & 0.272 & 0.200 & 0.301 & 0.114 \\
\hline
\end{tabular}


Table 6.4: Estimated coefficients and p-values from models with alternate proxies for degree of elitism (using OLS and LPM)

For wdaysnum

BFscore1
BFscore2
BFscore3
Average number of
dependence connections in
village

Coefficient

$-58.78+$

$-141.51 * *$

$-67.45^{* *}$

p-value

0.08

0

Number of observations

6.89

2231

0.32

For wdaysever

BFscore1

BFscore2

BFscore3

Average number of

dependence connections in

village

Number of observations

$\begin{array}{cc}\text { Coefficient } & \text { p-value } \\ -0.9 & 0.34 \\ -2.88^{* *} & 0.01 \\ -1.20+ & 0.06\end{array}$

$0.51 * *$

3344 
Diagram 2.1: All outgoing link in a village

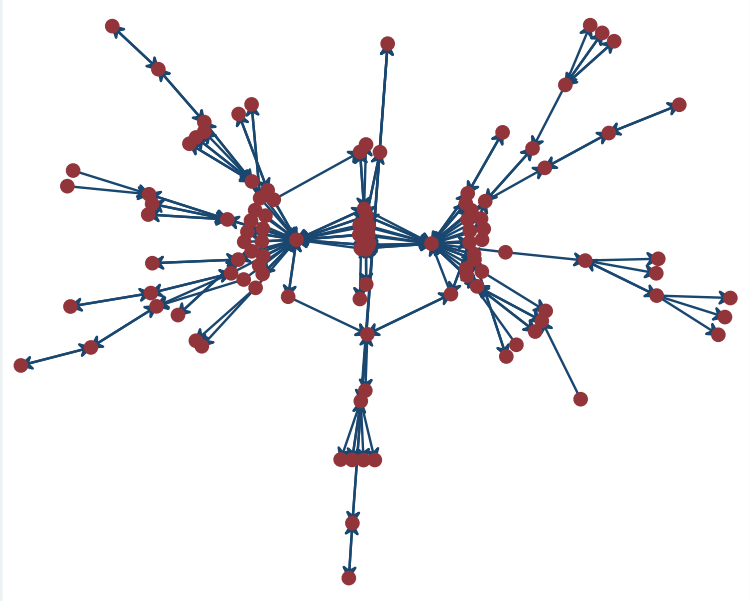

Diagram 2.2: All dependence -connection in two villages (a) Elite village

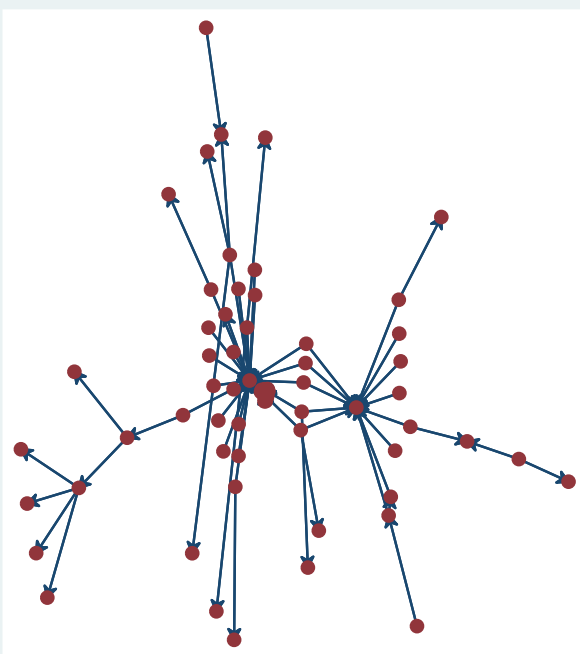


(b) Non-elite village

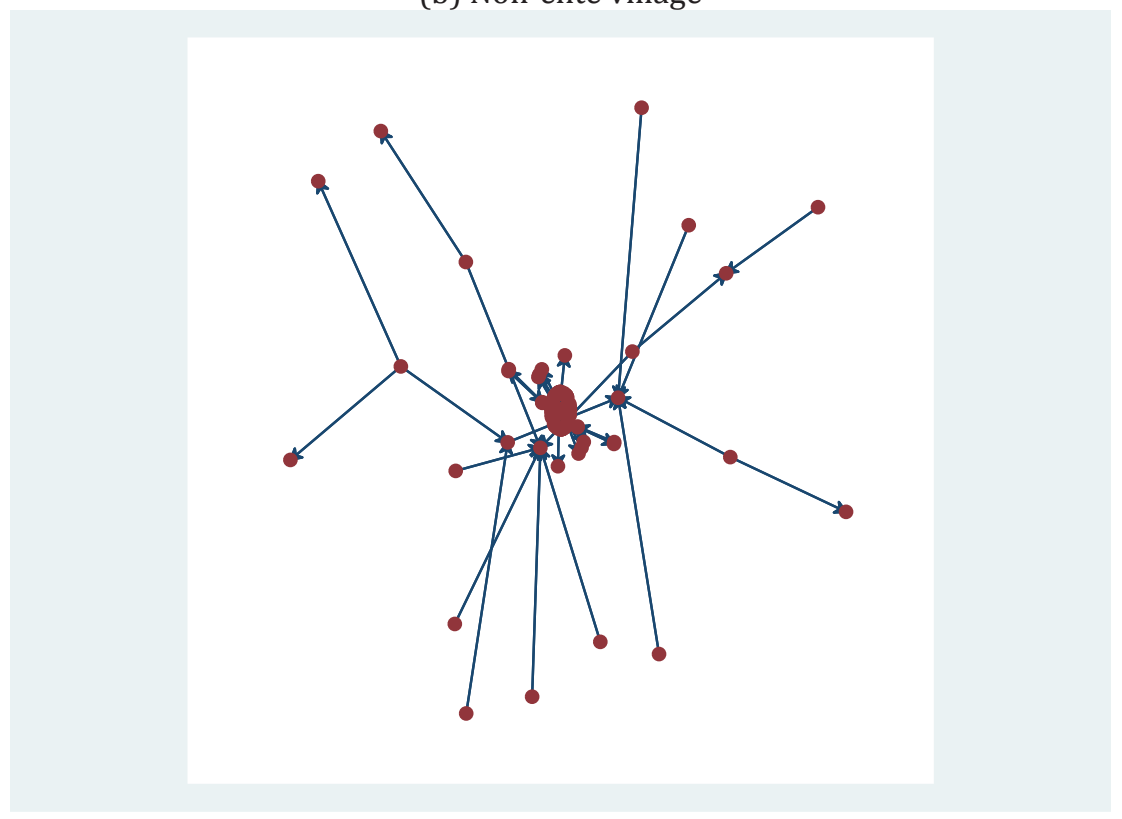

Diagram 3.1: Distribution of MGNREGS workdays in last 13 months prior to the survey by client status

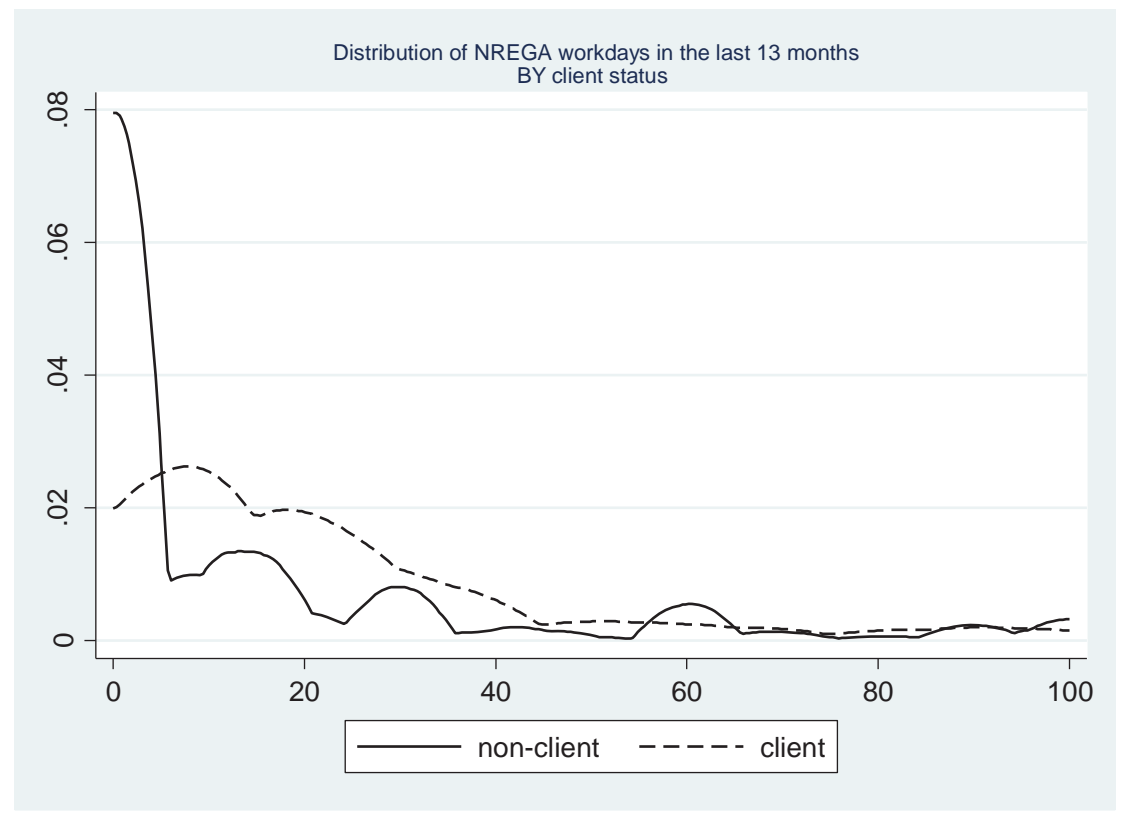




\section{A Proof of Theoretical Results}

\section{Proof of Proposition 1}

We complete the equilibrium computation here. Let us recall the following partition of parametric space

(i) $r \leq \underline{w} \leq \frac{e p_{0}}{p_{e}-p_{0}}+r:(\mathrm{ICW})$ and (ICO) are binding

(ii) $\frac{e p_{0}}{p_{e}-p_{0}}+\bar{b}>\underline{w}>\frac{e p_{0}}{p_{e}-p_{0}}+r$ : (ICW) and (IRO) are binding

(iii) $\underline{w} \geq \frac{e p_{0}}{p_{e}-p_{0}}+\bar{b}$ : (IRW) and (IRO) are binding

We formally add a lower bound on $R$; let us assume that $R>\max \left\{\frac{\bar{\rho}}{\bar{b}-r}, \frac{r}{r-\underline{b}}\right\}$, where $B^{\prime}(\bar{s})=\underline{b}$. Recall that $\bar{\rho}$ is the upper bound of $\rho$ and $B^{\prime}(0)=\bar{b}$. We have already mentioned that $\bar{b}>r$. Note that $z(\bar{s})=0$ implies $\frac{B(\bar{s})}{\bar{s}}=r$. Since $B$ is strictly concave and $B(0)=0, \underline{b}<\frac{B(\bar{s})}{\bar{s}}=r$.

Equilibrium in zone $(i)$ :

Continuing with backward induction, we compute voting decision by agricultural workers. Workers in $S_{i}$ an $S_{j}$, those who have borrowed from the politician-lenders face different incentives than those who have borrowed from moneylenders. Take a worker $k \in S_{i}$. His payoff from voting $i$ is $\left[\psi+\beta_{k}+\alpha\left(m_{i}-m_{j}\right)+E\left(\pi_{k} \mid i\right.\right.$ wins $\left.)\right]$. Here $E\left(\pi_{k} \mid i\right.$ wins $)$ is expected payoff of a worker in $S_{i}$ if $i$ wins. $\beta_{k}$ is the randomly drawn loyalty shock in favour of politician-lender $i$ over politician-lender $j$ and $\psi$ is an aggregate uncertainty parameter. We assume that aggregate uncertainty is also a random draw from uniform distribution $\left[-\frac{1}{2}, \frac{1}{2}\right]^{19}$.

$$
E\left(\pi_{k} \mid i \text { wins }\right)=p_{e}\left(\frac{e}{p_{e}-p_{0}}+z\left(s_{i}\left(1-p_{e}\right)\right)\right)+\left(1-p_{e}\right) z\left(s_{i}\left(1-p_{e}\right)\right)-e
$$

Since incentive constraint is binding for borrowers of the incumbent, $k$ gets $\left[\frac{e}{p_{e}-p_{0}}+z\left(s_{i}\left(1-p_{e}\right)\right)+r\right]$ when a harvest is successful. He fully repays the debt in that case. Otherwise $k$ only receives MGNREGS relief net of debt repayment.

Worker $k$ 's payoff from voting $j$ is $E\left(\pi_{k} \mid j\right.$ wins $)=\left[p_{e} \frac{e}{p_{e}-p_{0}}-e\right]$. Here also incentive constraint is binding for agents like $k$, who do not belong to $S_{j}$.

\footnotetext{
${ }^{19}$ Generalization is straightforward. We assume a simple form to avoid unnecessary notations.
} 
Therefore $k$ votes for $i$ if and only if

$$
\begin{array}{r}
\psi+\beta_{k}+\alpha\left(m_{i}-m_{j}\right)+p_{e}\left(\frac{e}{p_{e}-p_{0}}+z\left(s_{i}\left(1-p_{e}\right)\right)\right)+ \\
\left(1-p_{e}\right) z\left(s_{i}\left(1-p_{e}\right)\right)-e \geq p_{e} \frac{e}{p_{e}-p_{0}}-e
\end{array}
$$

which is equivalent to $\psi+\beta_{k}+\alpha\left(m_{i}-m_{j}\right)+z\left(s_{i}\left(1-p_{e}\right)\right) \geq 0$. Since $\beta_{k}$ is randomly drawn from a uniform $\left[-\frac{1}{2}, \frac{1}{2}\right]$ distribution, proportion of workers in $S_{i}$ who vote in favour of $i$ is given by $\left[\frac{1}{2}+\psi+\alpha\left(m_{i}-m_{j}\right)+z\left(s_{i}\left(1-p_{e}\right)\right)\right]$. Similarly, proportion of workers in $S_{j}$ who vote in favour of $i$ is $\left[\frac{1}{2}+\psi+\alpha\left(m_{i}-m_{j}\right)-z\left(s_{j}\left(1-p_{e}\right)\right)\right]$ and proportion of workers in $S_{M}$ who vote in favour of $i$ is $\left[\frac{1}{2}+\psi+\alpha\left(m_{i}-m_{j}\right)\right]$. Thus total vote share of $i$ is

$$
\begin{aligned}
s_{i}\left(\frac{1}{2}+\psi+\alpha\left(m_{i}-m_{j}\right)+z\left(s_{i}\left(1-p_{e}\right)\right)\right)+s_{j} & \left(\frac{1}{2}+\psi+\alpha\left(m_{i}-m_{j}\right)-z\left(s_{j}\left(1-p_{e}\right)\right)\right) \\
& +\left(1-s_{i}-s_{j}\right)\left(\frac{1}{2}+\psi+\alpha\left(m_{i}-m_{j}\right)\right)
\end{aligned}
$$

$\psi$ is a random draw from uniform $\left[-\frac{1}{2}, \frac{1}{2}\right]$. Probability that $i$ wins majority vote share is $\gamma_{i}=\left[\frac{1}{2}+\alpha\left(m_{i}-m_{j}\right)+s_{i} z\left(s_{i}\left(1-p_{e}\right)\right)-s_{j} z\left(s_{j}\left(1-p_{e}\right)\right)\right]$.

Landowners' choice of $m_{i}$ and $m_{j}$ can be obtained by maximizing their profit function. If politician-lender $i$ wins the election then $s_{i}$ workers are to be paid at a higher rate of $\left[\frac{e}{p_{e}-p_{0}}+z\left(s_{i}\left(1-p_{e}\right)\right)+r\right]$, while the rest are paid at the rate of $\left[\frac{e}{p_{e}-p_{0}}+r\right]$. Similarly if $j$ is elected then $s_{j}$ workers are paid at a higher rate of $\left[\frac{e}{p_{e}-p_{0}}+z\left(s_{j}\left(1-p_{e}\right)\right)+r\right]$. Landowners revenue from a successful harvest is denoted by $q$. Profit of landowners is

$$
\begin{array}{r}
\gamma_{i} p_{e}\left[\left(q-\left[\frac{e}{p_{e}-p_{0}}+r\right]\right)-s_{i} z\left(s_{i}\left(1-p_{e}\right)\right)\right] \\
+\left(1-\gamma_{i}\right) p_{e}\left[\left(q-\left[\frac{e}{p_{e}-p_{0}}+r\right]\right)-s_{j} z\left(s_{j}\left(1-p_{e}\right)\right)\right]-\frac{1}{2}\left(m_{i}+m_{j}\right)^{2}
\end{array}
$$

First line of this equation is land owners' payoff when $i$ wins the election multiplied by probability of $i$ 's win. Next line is land owners' payoff when $j$ wins the election multiplied by probability of $j$ 's win. Note that $\gamma_{i}$ is a function of 
$m_{i}$ and $m_{j}$. Cost of campaign effort is $\frac{1}{2}\left(m_{i}+m_{j}\right)^{2}$. This can be rewritten as,

$$
\begin{array}{r}
p_{e}\left(q-\frac{e}{p_{e}-p_{0}}-r\right)-p_{e} s_{j} z\left(s_{j}\left(1-p_{e}\right)\right) \\
-p_{e} \gamma_{i}\left[s_{i} z\left(s_{i}\left(1-p_{e}\right)\right)-s_{j} z\left(s_{j}\left(1-p_{e}\right)\right)\right]-\frac{1}{2}\left(m_{i}+m_{j}\right)^{2}
\end{array}
$$

First two terms are independent of $m_{i}, m_{j}$. At the maximum,

if $\left[s_{i} z\left(s_{i}\left(1-p_{e}\right)\right)-s_{j} z\left(s_{j}\left(1-p_{e}\right)\right)\right]>0$ then $m_{j}=\alpha p_{e}\left[s_{i} z\left(s_{i}\left(1-p_{e}\right)\right)-s_{j} z\left(s_{j}\left(1-p_{e}\right)\right)\right]$ and $m_{i}=0$

if $\left[s_{i} z\left(s_{i}\left(1-p_{e}\right)\right)-s_{j} z\left(s_{j}\left(1-p_{e}\right)\right)\right]<0$ then $m_{i}=-\alpha p_{e}\left[s_{i} z\left(s_{i}\left(1-p_{e}\right)\right)-s_{j} z\left(s_{j}\left(1-p_{e}\right)\right)\right]$ and $m_{j}=0$

Using these optimal values of $m_{i}, m_{j}$, we obtain,

$$
\bar{\gamma}_{i}=\frac{1}{2}+\left(1-\alpha^{2} p_{e}\right)\left(s_{i} z\left(s_{i}\left(1-p_{e}\right)\right)-s_{j} z\left(s_{j}\left(1-p_{e}\right)\right)\right)
$$

Finally, we are ready to compute the equilibrium choice of $s_{i}$ and $s_{j}$. Given $s_{j}$, politician-lender $i$ chooses $s_{i}$ to maximize

$$
\begin{array}{r}
\bar{\gamma}_{i}\left[R+s_{i}\left(p_{e} r+\left(1-p_{e}\right) \min \left\{\frac{B\left(s_{i}\left(1-p_{e}\right)\right)}{s_{i}\left(1-p_{e}\right)}, r\right\}-\rho\right)\right] \\
+\left(1-\bar{\gamma}_{i}\right)\left[s_{i}\left(p_{e} r-\rho\right)\right]
\end{array}
$$

Political rent from holding the office is $R$, while opportunity cost of 1 unit of fund is $\rho$.

In equilibrium, $s_{i}\left(1-p_{e}\right)$ must be less than $\bar{s}$. Otherwise workers are indifferent between moneylenders and politician-lenders and by assumption will borrow from moneylenders. When $s_{i}\left(1-p_{e}\right) \leq \bar{s}$, politician-lenders' payoff is

$$
\bar{\gamma}_{i}\left[R+s_{i}(r-\rho)\right]+\left(1-\bar{\gamma}_{i}\right)\left[s_{i}\left(p_{e} r-\rho\right)\right]
$$

First order condition is

$$
\frac{d \bar{\gamma}_{i}}{d s_{i}}\left[R+s_{i} r\left(1-p_{e}\right)\right]+\bar{\gamma}_{i}(r-\rho)+\left(1-\bar{\gamma}_{i}\right)\left(p_{e} r-\rho\right)=0
$$

In symmetric equilibrium $s_{i}=s_{j}=s$ and $\bar{\gamma}_{i}=\frac{1}{2}$. First order condition can 
be rewritten as

$$
\begin{array}{r}
\frac{\left(1-\alpha^{2} p_{e}\right)}{\left(1-p_{e}\right)}\left(B^{\prime}\left(s\left(1-p_{e}\right)\right)-r\right)\left[R+s r\left(1-p_{e}\right)\right] \\
+\frac{1}{2}\left(r\left(1+p_{e}\right)-2 \rho\right)=0
\end{array}
$$

It can be easily checked that at $s=0$, LHS of Equation (3) is positive and at $s\left(1-p_{e}\right)=\bar{s}$, it is negative. By continuity, there exists $0<s<\bar{s}$ that satisfies the first order condition. Assumption (A2) ensures that equilibrium client size of a politician-lender is strictly below $\frac{1}{2}$.

We have already shown that only the clients of incumbent are offered MGNREGS jobs in equilibrium. At symmetric equilibrium, fraction of $S_{i}$ who will vote for $i$ is $\left[\frac{1}{2}+z\left(s_{i}\left(1-p_{e}\right)\right)\right]$ which is strictly greater than $\frac{1}{2}$. Thus clients are more likely to vote for their respective patrons.

Equilibrium in zone $(i i)$ :

Calculations are similar to zone $(i)$ and hence we avoid repetition as much as possible. Probability that $i$ wins majority is

$$
\gamma_{i}=\frac{1}{2}+\alpha\left(m_{i}-m_{j}\right)+s_{i} z\left(s_{i}\left(1-p_{e}\right)\right)-s_{j} z\left(s_{j}\left(1-p_{e}\right)\right)+\Delta\left(s_{j}-s_{i}\right)
$$

where $\Delta=\left[\underline{w}-\frac{e p_{0}}{p_{e}-p_{0}}-r\right]$. Note that $\Delta>0$. It is straightforward to check that landowners' optimal choice of $m_{i}, m_{j}$ remain the same as zone $(i)$. Therefore

$$
\bar{\gamma}_{i}=\frac{1}{2}+\left(1-\alpha^{2} p_{e}\right)\left(s_{i} z\left(s_{i}\left(1-p_{e}\right)\right)-s_{j} z\left(s_{j}\left(1-p_{e}\right)\right)\right)+\Delta\left(s_{j}-s_{i}\right)
$$

Solving politician-lender's optimization problem, we obtain, in symmetric equilibrium,

$$
\begin{array}{r}
{\left[\frac{\left(1-\alpha^{2} p_{e}\right)}{\left(1-p_{e}\right)}\left(B^{\prime}\left(s\left(1-p_{e}\right)\right)-r\right)-\Delta\right]\left[R+s r\left(1-p_{e}\right)\right]} \\
+\frac{1}{2}\left(r\left(1+p_{e}\right)-2 \rho\right)=0
\end{array}
$$

At $s\left(1-p_{e}\right)=\bar{s}$, LHS of Equation (3) is negative as in zone $(i)$ because $\Delta>0$. Now suppose that $\rho \leq \frac{1}{2} r\left(1+p_{e}\right)$. LHS of Equation (4) is positive at $s=0$ because $\alpha<1$ and $\underline{w}<\frac{e p_{0}}{p_{e}-p_{0}}+\bar{b}$. Thus there exist a clientelistic 
equilibrium in zone $(i i)$ for all $\rho \leq \frac{1}{2} r\left(1+p_{e}\right)$. For every $\rho>\frac{1}{2} r\left(1+p_{e}\right)$, there exists a cutoff $\underline{w}^{\star}$ such that LHS of Equation (4) is zero at $s=0$. For all $\underline{w}<\underline{w}^{\star}$, LHS of Equation (4) is positive at $s=0$ and hence the size of clientele is strictly positive in equilibrium. For all $\underline{w} \geq \underline{w}^{\star}$ there is no clientelism in equilibrium.

In zone (iii), both individual rationality constraints (IRW) and (IRO) are binding. Given our assumption that indifferent workers will borrow from moneylenders, there is no client in equilibrium. This completes the proof of Proposition 1.

\section{Proof of Proposition 2}

Proof of part $(a)$ and $(b)$ are straightforward. They follow from Proposition 1, Equations (3) and (4). We only provide a proof of part $(c)$ for zone $(i)$. Using implicit function theorem on Equation (3), we obtain $\frac{d s}{d \alpha}=\frac{2 \alpha p_{e} G_{0}}{\left(1-\alpha^{2} p_{e}\right)\left(G_{1}+G_{2}\right)}$ where

$$
\begin{array}{r}
G_{0}=\left(B^{\prime}\left(s\left(1-p_{e}\right)\right)-r\right)\left(R+s r\left(1-p_{e}\right)\right) \\
G_{1}=\left(B^{\prime}\left(s\left(1-p_{e}\right)\right)-r\right) r\left(1-p_{e}\right) \\
G_{2}=\left(R+s r\left(1-p_{e}\right)\right)\left(1-p_{e}\right) B^{\prime \prime}\left(s\left(1-p_{e}\right)\right)
\end{array}
$$

By second order condition, the denominator is negative. Therefore $\frac{d s}{d \alpha}$ and $\left(B^{\prime}\left(s\left(1-p_{e}\right)\right)-r\right)$ have opposite signs. From Equation (3), we also know that $\left(\rho-\frac{1}{2} r\left(1+p_{e}\right)\right)$ and $\left(B^{\prime}\left(s\left(1-p_{e}\right)\right)-r\right)$ have the same sign. Therefore $\frac{d s}{d \alpha}$ is positive when $\rho \leq \frac{1}{2} r\left(1+p_{e}\right)$ and negative otherwise. The proof is similar in zone $(i i)$. 


\section{B List of variables}

\begin{tabular}{|c|c|c|}
\hline \multicolumn{3}{|c|}{$\begin{array}{l}\text { Household-level variables } \\
\text { Source: Household questionnaire of our survey }\end{array}$} \\
\hline Variable Name & Description & Definition \\
\hline wdaysever & $\begin{array}{l}\text { Participation in MGNREGS } \\
\text { work since its introduction }\end{array}$ & $\begin{array}{l}\text { 1: if ever participated } \\
0: \text { otherwise }\end{array}$ \\
\hline wdaysnum & $\begin{array}{l}\text { Number of MGNREGS } \\
\text { workdays in last } 13 \text { months } \\
\text { prior to the survey }\end{array}$ & Number of days \\
\hline caste & $\begin{array}{l}\text { Caste and religion of } \\
\text { household head }\end{array}$ & $\begin{array}{l}\text { Five categories: } \\
\text { - Upper: if Brahmin/ General } \\
\text { - } \quad \text { Lower: if SC/ST/NT } \\
\text { - OBC: if OBC } \\
\text { - Muslim: if religion is Muslim } \\
\text { - } \quad \text { Other: if none of the above }\end{array}$ \\
\hline land owned & $\begin{array}{l}\text { Total rural land owned by } \\
\text { household }\end{array}$ & In Acre \\
\hline non-land asset & Index of asset ownership & $\begin{array}{l}\text { Sum of following six dummy } \\
\text { variables. Each take value } 1 \text { if } \\
\text { owned by the household and } 0 \\
\text { otherwise. } \\
\text { - Non-kacha (mud built and } \\
\text { thatched roof) house } \\
\text { - Flat/house in town } \\
\text { - Palang } \\
\text { - TV } \\
\text { - Two/four wheelers } \\
\text { - Tree/ fruit bearing plant }\end{array}$ \\
\hline stable occupation & $\begin{array}{l}\text { Main household occupation as } \\
\text { identified by the household } \\
\text { head }\end{array}$ & $\begin{array}{l}\text { 1: if running a business/factory/ } \\
\text { production unit or salaried } \\
\text { position in some organization } \\
0: \text { if any other occupation }\end{array}$ \\
\hline remittance received & $\begin{array}{l}\text { Remittance from outside the } \\
\text { village }\end{array}$ & $\begin{array}{l}\text { 1: if someone living outside the } \\
\text { village sends money to the } \\
\text { household } \\
0 \text { : otherwise }\end{array}$ \\
\hline potential workers & $\begin{array}{l}\text { Number of household members } \\
\text { with education below } \\
\text { secondary level and age } \\
\text { between } 16 \text { and } 60\end{array}$ & Headcount \\
\hline $\begin{array}{l}\text { maximum education } \\
\text { in household }\end{array}$ & $\begin{array}{l}\text { Maximum level of education } \\
\text { among all the members of a } \\
\text { household }\end{array}$ & $\begin{array}{l}\text { Three categories: } \\
\text { - Up to higher secondary } \\
\text { education } \\
\text { - Under-graduation or } \\
\text { equivalent degrees } \\
\text { - } \quad \text { Above under-graduation }\end{array}$ \\
\hline
\end{tabular}




\begin{tabular}{|c|c|c|}
\hline $\begin{array}{l}\text { socio-political } \\
\text { influence }\end{array}$ & $\begin{array}{l}\text { Formal institutional position } \\
\text { hold by some household } \\
\text { member }\end{array}$ & $\begin{array}{l}\text { 1: if a member of household } \\
\text { is/was panchayat pradhan/ } \\
\text { member of local government/ } \\
\text { position holder of political party, } \\
\text { union } \\
0: \text { otherwise }\end{array}$ \\
\hline advice given & $\begin{array}{l}\text { Involvement of household } \\
\text { members in mediating } \\
\text { community disputes }\end{array}$ & $\begin{array}{l}\text { 1: if household members mediate } \\
\text { in community disputes } \\
0: \text { otherwise }\end{array}$ \\
\hline $\begin{array}{l}\text { experience with } \\
\text { local administration }\end{array}$ & $\begin{array}{l}\text { Experience of dealing with } \\
\text { formal institutions such as } \\
\text { police, court }\end{array}$ & $\begin{array}{l}\text { 1: if any household member has } \\
\text { experience of dealing with police, } \\
\text { court, bureaucracy } \\
0 \text { : otherwise }\end{array}$ \\
\hline \multicolumn{3}{|c|}{$\begin{array}{l}\text { Village-level variables } \\
\text { Source: Village questionnaire of our survey, if not otherwise mentioned }\end{array}$} \\
\hline Variable Name & Description & Definition \\
\hline distance to town & Distance to the nearest town & In Kilometer \\
\hline average rainfall & Average rainfall in the village & $\begin{array}{l}\text { Millimeter } \\
\text { Source: India Meteorological } \\
\text { Department }\end{array}$ \\
\hline irrigation & $\begin{array}{l}\text { Proportion of sown area of the } \\
\text { village which is irrigated }\end{array}$ & $\begin{array}{l}\text { Percentage } \\
\text { Source: } 2011 \text { Census }\end{array}$ \\
\hline percentage labour & $\begin{array}{l}\text { Proportion of households in the } \\
\text { village for which agriculture or } \\
\text { working as agricultural labour } \\
\text { is the main occupation }\end{array}$ & $\begin{array}{l}\text { Percentage } \\
\text { Source: } 2011 \text { Census }\end{array}$ \\
\hline
\end{tabular}




\section{Sample Design}

The LIREP survey sample has a multi-stage, clustered and stratified design. The target sample size was 3600 households. As mentioned above, one of the key information that this survey aimed to collect was the local dependence structure and so it was essential to collect information from all or a large percentage of households in each village. So, it was decided to select and interview approximately 100 households from each of the selected villages which meant that 36 villages could be selected in the sample.

India is a vast country with 29 states and union territories and each of these regions are culturally and politically different with many policies being implemented at the regional level. To be able to control for these state level effects it was decided to confine the sample to three states so that we had sufficient sample sizes at the state level. The three states chosen were Orissa, Maharashtra and (the Eastern part) of Uttar Pradesh. These three states or sub-state regions were chosen because of the presence of LWE activity and because across these regions there was sufficient variation in land revenue systems during the colonial period which is famously known to be a factor affecting institutional variations within Indian villages.

Stage 1: Selecting blocks using a stratified design

To increase the variability of the sample along a number of characteristics and to ensure enough sample sizes for one of the key variables of interest, left wing extremism, it was decided to stratify the sample along these characteristics. Most of the information were available at the district or block (a smaller geographical unit than the district) level. So, it was decided to first select blocks from each of the different strata using probability proportion to size (PPS) sampling where size was measured by the number of households in the block (as in 2001 Census of India, the latest that was available to us) and then select a village randomly from the selected blocks again using PPS sampling method where size was measured by the number of households in the village. The characteristics used for stratification for each state sub-sample were as follows:

- Whether the block had experienced left wing extremist activities (L) or not (NL) between the period 2005 to 2010. This was identified using a number of different sources.

- Whether the district containing the block was in coastal (C) or noncoastal region $(\mathrm{NC})$ : identified directly from maps. Coastal regions 
were expected to have occupational diversity while people in more interior regions were expected to be mainly in agricultural occupation. To be able to identify different types of dependence, not only predominantly agriculture-based dependence links, the sample was also stratified by coastal and non-coastal region.

- Whether historically the district was under ryotwari or non-ryotwari system during the colonial rule: identified using classification provided by Bannerjee and Iyer ([9]).

These criteria resulted in the population being divided into 12 mutually exclusive and exhaustive 12 strata within the three states with the added constraint that 12 blocks would have to be selected from each region. As some analysis would look at the LWE impact it was also decided that there should be a sufficient number of villages from the LWE stratum. Hence the following stratification strategy was implemented. Ignoring the clustering of households within villages, the deff was computed to be 1.489 and the neff was 2820 .

Stage 2: Assigning selected blocks to forest and non-forest sub-samples

The next sampling stage was to select one village from each selected block. In the first sampling stage one of the variables we had stratified by was LWE activity. But as blocks are large areas with on average 170 villages (and 50\% of blocks have more than 150 villages but $99 \%$ of blocks have less than 550 villages), not all villages are affected by LWE activity. As it was extremely difficult to get precise information on exactly which of the several hundreds of villages in a block has a history of LWE activities, we decided to indirectly screen for LWE affected villages by selecting villages in these LWE affected blocks that were very near to forest as forest cover has been found to be highly correlated with LWE activity at least at the district level and there is anecdotal evidence that LWE organisations mainly base their activities in dense forests as state forces find it difficult to enter these areas. So, we then decided to draw two sub-samples from LWE affected blocks - one from areas next to forests and the other from areas away from forests. We did this by collecting maps of forest cover from the Geological Survey of India and the Forest Research Institute and then overlay those on maps of villages. We decided to assign the following number of blocks to the village sub-sample.

- Strata: Eastern UP- L,NC,NR: As one of the selected blocks in the L,NC,NR strata of Eastern UP had no forested village, this block was 
automatically assigned to the non-forested sub-sample and the remaining blocks in those strata since they summed up to the assigned number of blocks for the Forest Sub-Sample, were allocated to the Forest SubSample.

- Strata: Orissa - L,CO,NR: As one of the selected blocks in L, CO, NR strata in Orissa had no forested village, this block was automatically assigned to the non-forested sub-sample and the remaining blocks in those strata since they summed up to the assigned number of blocks for the Forest Sub-Sample, were allocated to the Forest Sub-Sample.

- Strata: Orissa - L,NC,NR: We selected 2 out of the 3 blocks by PPS where size measure was the proportion of households in forested villages in these blocks.

- Strata: Orissa - L,NC,RY: The only selected block from this stratum was automatically assigned to the Forest Sub-Sample.

- Strata: Maharashtra - L,NC,NR: We selected 3 out of the 4 blocks by PPS where size measure was the proportion of households in forested villages in these blocks.

Stage 3: Selecting villages from selected blocks

Finally we selected one village from each of the 36 selected blocks using PPS where size measured by the total number of households in the village.

Stage 4: Selecting households from selected villages

In villages where the total number of households was less than 100 all households were selected. In villages where the total number of households was more than 100 up to 110 households were selected from the selected villages using simple random sampling. The sampling frame used was the most recent electoral roll for those villages. The target was to interview at least 100 households in each village and at most 110 households. In some cases, 100 households could not be found. In such cases additional households were selected from the remaining households in the villages again using simple random sampling to reach the target sample size.

In the final sample, 21 of the sampled villages included less than $50 \%$ of the HHs in the villages, 5 included $50-60 \%$ of the HHs in the villages, 3 included $60-70 \%$ of the HHs in the villages, 2 included $80-95 \%$ of the HHs in the villages and 4 were village censuses. 